\title{
DIGITALCOMMONS
}

@WAYNESTATE-

Wayne State University

Law Faculty Research Publications

Law School

1-1-2009

\section{The Michigan Supreme Court, Stare Decisis, and Overruling the Overrulings}

Robert A. Sedler

Wayne State University, rsedler@wayne.edu

\section{Recommended Citation}

Robert A. Sedler, The Michigan Supreme Court, Stare Decisis, and Overruling the Overrulings, 55 Wayne L. Rev. 1911 (2009). Available at: http://digitalcommons.wayne.edu/lawfrp/92

This Article is brought to you for free and open access by the Law School at DigitalCommons@WayneState. It has been accepted for inclusion in Law Faculty Research Publications by an authorized administrator of DigitalCommons@WayneState. 


\title{
THE MICHIGAN SUPREME COURT, STARE DECISIS, AND OVERRULING THE OVERRULINGS
}

\author{
ROBERT A. SEDLER ${ }^{\dagger}$ \\ Table of Contents
}

I. INTRODUCTION

II. THE FUNCTION OF STARE DECISIS IN THE AMERICAN LEGAL SYSTEM

III. STARE DECISIS AND THE PRACTICE OF THE U.S. SUPREME

COURT

IV. PRIOR DECISIONS AND THE DEVELOPMENT OF THE COMMON LAW

V. THE ABANDONMENT OF STARE DECISIS BY THE MICHIGAN

SUPREME COURT...

VI. THE Michigan SUPREME COURT AND A RETURN TO STARE DECISIS

VII. CONCLUSION 1951

\section{INTRODUCTION}

The principle of stare decisis dictates that in the absence of a special justification for overruling a prior decision, a court must follow its prior decisions even though a majority of the court, as currently constituted, believes that the prior decision was wrongly decided.

In this Article, I will discuss and analyze the abandonment of stare decisis by the Michigan Supreme Court in the period from 1999 to 2008. During that time, a new Michigan Supreme Court majority, consisting of Justices Corrigan, Markman, Taylor, and Young, overruled by my count thirty-eight cases, some no more than a few years old. While four of these overrulings may be considered non-ideological in the sense that all of the justices concurred in the decision to overrule, the remaining thirtyfour overrulings were clearly ideological. In every civil case, the result of the overruling of the prior decision was to favor defendants over plaintiffs by limiting liability or by making it more difficult for the plaintiffs to assert a claim. In every criminal case, the result of the overruling of the prior decision was to favor the prosecution over the defendant and to uphold a conviction against the defendant's constitutional or statutory claim. While the Court majority paid some lip service to the principle of stare decisis and sometimes tried to justify the 
particular overruling as being justified for other reasons, the primary reason that the majority gave for overruling the prior decision was that it believed that the prior case was wrongly decided.

What has happened in Michigan, purely and simply, is that a majority of the justices on the Michigan Supreme Court overruled prior decisions with which they disagreed, in order to advance the majority's policy objectives. Because this is so, the legitimacy of the Court's abandonment of stare decisis and the large number of ideologicallybased overrulings during this period may properly be called into question.

In the 2008 election, Chief Justice Taylor was defeated for reelection by Wayne County Circuit Judge Diane Hathaway. This brought to an end the Court majority that had abandoned stare decisis and that had engaged in an unprecedented overruling of the Court's prior decisions. A new Court majority is now faced with the question of whether and how it will go about restoring the principle of stare decisis to Michigan jurisprudence and of confronting the consequences of the former Court majority's abandonment of stare decisis.

I will begin by discussing the function of stare decisis in the American legal system and the practice of the U.S. Supreme Court with respect to stare decisis. I will next discuss prior decisions in relation to the development of the common law in Michigan. I will then discuss the abandonment of stare decisis by the Michigan Supreme Court in the period from 1999 to 2008. In the concluding section of this Article I will discuss a return to stare decisis by the Michigan Supreme Court and will offer some proposals as to how the Court, as now constituted, can confront the consequences of the former Court majority's abandonment of stare decisis.

\section{THE FUNCTION OF STARE DECISIS IN THE AMERICAN LEGAL SYSTEM}

We rely on the courts to provide the law of the American legal system. The courts promulgate and apply the common law, they define the meaning of the federal and state constitutions, and they interpret the statutes enacted by the legislative bodies. In practice, the law of the American legal system is found primarily in the decisions of the courts, and it is from these decisions that we derive doctrine and precedent. In order for the courts to perform their multiple functions in the American legal system, the courts must follow their own decisions in subsequent cases. This means that a decision once rendered should not be overruled unless there is a special justification for overruling that decision. The concept that courts should follow their own decisions in subsequent cases is embodied in the principle of stare decisis (Latin for "let the decision 
stand"), and as the United States Supreme Court has observed, stare decisis is generally "the preferred course because it promotes the evenhanded, predictable, and consistent development of legal principles, fosters reliance on judicial decisions, and contributes to the actual and perceived integrity of the judicial process." Of course, as the Supreme Court has also observed, "stare decisis is a 'principle of policy' rather than an "inexorable command"'2 and there will be times when a special justification for overruling a prior decision can be shown. When this is so, the decision will be overruled, and the new decision is incorporated into the body of doctrine and precedent that the Court applies.

However, in the absence of special justification for overruling a prior decision, the principle of stare decisis dictates that a judge must follow the prior decisions of the court on which the judge sits even if the judge believes that the prior decision was wrongly decided. The duty to follow prior decisions is no less cogent when a majority of the judges on a court as constituted at a given point in time believes that the prior decision was wrongly decided. Obviously when a court majority believes that a prior decision was wrongly decided, the court will be strongly disposed to limit the scope of that decision and will not extend it to cases to which it might be applied. ${ }^{3}$ But in the absence of a special justification for

$\dagger$ Distinguished Professor of Law, Wayne State University Law School. A.B., 1956, University of Pittsburgh; J.D., 1959, University of Pittsburgh School of Law.

1. Hohn v. United States, 524 U.S. 236, 251 (1998) (quoting Payne v. Tennessee, 501 U.S. 808, 827 (1991)).

2. Id. at 251 (internal citations omitted).

3. Sometimes, when a Court limits significantly the scope of a prior decision, the dissenters will contend that the Court has effectively overruled it. For example, in the recent case of Arizona v. Gant, 129 S. Ct. 1710 (2009), the U.S. Supreme Court gave a narrow reading to its earlier decision in New York v. Belton, 453 U.S. 454 (1981), where the Court held that the police could search the passenger compartment of a vehicle and any containers therein as a contemporaneous incident of the arrest of the vehicle's recent occupant. Grant, $129 \mathrm{~S}$. Ct. at 1717-18. In Gant, a sharply divided Court held 5-4 that Belton did not authorize a vehicle search incident to the arrest of a recent occupant after the arrestee had been secured and could not access the interior of the vehicle. Id. at 172 . The Court majority said that its opinion in Belton "has been widely understood to allow a vehicle search incident to the arrest of a recent occupant even if there is no possibility the arrestee could gain access to the vehicle at the time of the search." Id. at 1718. After distinguishing Belton on its facts, $I d$. at 1719 , the Court stated that "[t]he experience of the twenty-eight years since we decided Belton has shown that the generalization underpinning the broad reading of that decision is unfounded. Id. at 1723. We now know that articles inside the passenger compartment are rarely "within 'the area into which an arrestee might reach"" and blind adherence to Belton's faulty assumption would authorize myriad unconstitutional searches. Id. at 1723 (citing Belton, 453 U.S. at 460). The doctrine of stare decisis does not require us to approve routine constitutional violations." Gant, 129 S. Ct. at 1723 . Justice Scalia wanted to overrule Belton and Thornton v. United States, 541 U.S. 615 (2004), which allowed a warrantless search when it was reasonable 
overruling, a court must follow its prior decision in a case where it is clearly applicable and where it cannot be distinguished in any principled way. Stated simply, when a judge becomes a member of a court, the judge must accept prior decisions as controlling and must operate within the framework of the doctrine and precedent established by the court's prior decisions.

\section{STARe Decisis AND the Practice of the United STATES SUPREME COURT}

The practice of the United States Supreme Court over a period of some 200 years can furnish guidance to other courts on the matter of special justification for overruling prior decisions. It has been very rare for the Supreme Court to overrule a prior decision on the ground that a majority of the Court as currently constituted believes that the prior decision was wrongly decided. ${ }^{4}$ Rather, the Court has emphasized that it should not overrule prior decisions due to a "present doctrinal disposition

to believe that the vehicle contained evidence of the offense of arrest. Gant, $129 \mathrm{~S}$. Ct. at 1725 (Scalia, J., concurring). But since no other justice was willing to overrule these cases, in order to avoid a 4-1-4 split that "leaves the governing rule uncertain," Justice Scalia joined the Stevens opinion, "acceding to what seems to me the artificial narrowing of these cases" contained in that opinion. Id. The dissenting justices, in the principal opinion by Justice Alito, contended that "[ $t]$ oday's decision effectively overrules these important decisions," and that "[a]lthough the Court refused to acknowledge that it is overruling Belton and Thornton, there can be no doubt that it does so." Id. at 1726 (Alito, J., dissenting). The dissenting justices further contended that looking to the Court's considerations for the overruling of prior decisions, that there was no "special justification" for overruling Belton and Thornton. Id. at 1726-32.

4. One glaring exception to this practice has been with respect to Congressional regulation of the states as states under Congress' power to regulate interstate commerce. After first holding that there was no state sovereignty limitation on Congress' power to apply laws enacted under the interstate commerce power to state and local governments in Maryland v. Wirtz, 392 U.S. 183 (1968), the Court overruled Wirtz in Nat'l League of Cities v. Usery, 426 U.S. 833, 849-52 (1976), where it held that Congress could not require the states to "substantially restructure" their integral operations in areas of "traditional governmental function." Then a series of cases followed where the state activity in question, such as operating a commuter railroad in United Transp. Union $v$. Long Island R.R., 455 U.S. 678 (1982), was held not to constitute a "traditional governmental function." Finally, in Garcia v. San Antonio Metro. Transit Auth., 469 U.S. 528 (1985), the Court concluded that federalism considerations did not require a state sovereignty limitation on Congress' otherwise plenary power over interstate commerce and overnuled Usery. The only limitation on Congress' power to regulate the states as states is that Congress cannot require the states to act or regulate in a non-preemptible area in accordance with federal standards. See Printz v. United States, 521 U.S. 898 (1997) (holding that Congress cannot require state law enforcement officers to carry out background checks for handgun purchases pursuant to a federal regulatory scheme). 
to come out differently than an [earlier] Court" and that "[t]o overrule prior law for no other reason than that would run counter to the view repeated in our cases, that a decision to overrule should rest on some special reason over and above the belief that a prior case was wrongly decided."

In Planned Parenthood of Southeastern Pennsylvania v. Casey, ${ }^{6}$ the Court set out guidelines for the overruling of prior decisions, stating that when it considers overruling a prior decision, "its judgment is customarily informed by a series of prudential and pragmatic considerations designed to test the consistency of overruling a prior decision with the ideal of the rule of law, and to gauge the respective costs of reaffirming and overruling a prior case."7 These considerations include: "whether the rule has proven to be intolerable simply in defying practical workability; ${ }^{8}$ whether the rule is subject to a kind of reliance

5. Planned Parenthood of Se. Pa. v. Casey, 505 U.S. 833, 864 (1992). Of course, when a court decides to overrule its decision in a prior case, the court has necessarily concluded that the prior case was wrongly decided. But, standing alone, this cannot be a special justification for overruling that decision.

6. Casey, 505 U.S. at 864.

7. Id. at 854 .

8. Id. The application of this guideline is illustrated by the Court's recent decision in Montejo v. Louisiana, 129 S. Ct. (2009), where the Court, in a 5-4 decision, overruled its earlier decision in Michigan v. Jackson, 475 U.S. 625 (1986). In Jackson, the Court held that the police could not initiate interrogation of a criminal defendant once the defendant had requested counsel at an arraignment or similar proceeding. In Montejo, the defendant had been arrested in connection with a robbery and murder. Montejo waived his rights under Miranda v. Arizona, 384 U.S. 436 (1966), and was interrogated over a period of time by police detectives. During the interrogation, he repeatedly changed his account of the crime. He was then brought before a judge for a preliminary hearing, and in accordance with Louisiana law, the judge ordered that the state Office of Indigent Defender be appointed to represent him, although he himself had not requested the appointment of counsel. Later in the day, two police detectives visited him back at the prison and requested that he accompany them on an excursion to locate the murder weapon, which he had earlier indicated that he had thrown into the lake. After some back and forth between him and the police, he was again read his Miranda rights, and he agreed to go along with the police. During the excursion, Montejo wrote an inculpatory letter of apology to the victim's widow. Only upon their return did Montejo finally meet his court-appointed attorney, who was quite upset that the detectives had interrogated his client in his absence. At the trial, the letter of apology was admitted over defense objection. The jury convicted Montejo of first-degree murder and sentenced him to death. Montejo, 129 S. Ct. at 2082. In Jackson, the Supreme Court held that "if police initiate interrogation after a defendant's assertion, at an arraignment or similar proceeding, of his right to counsel, any waiver of the defendant's right to counsel for that police-initiated interrogation is invalid." Jackson, 475 U.S. at 636. The Court in Montejo took the position that when a court appoints counsel for an indigent defendant in the absence of a request on the defendant's part to do so, there was no basis for a presumption that any subsequent waiver of the right to counsel would be involuntary. Montejo, $129 \mathrm{~S}$. Ct. at 
that would lend a special hardship to the consequences of overruling and add inequity to the cost of repudiation; whether related principles of law have so far developed as to have left the old rule no more than a remnant of abandoned doctrine; or whether facts have so changed, or come to be seen so differently, as to have robbed the old rule of significant application or justification."

2086. The Court also took the position that the rule of Jackson worked well enough in states that require the indigent defendant formally to request counsel before any appointment is made, which usually occurs after the court has informed the defendant that counsel will be appointed if the defendant asks for it, which is the practice in Michigan. But the Court noted that in a number of states like Louisiana, counsel is automatically appointed upon a finding of indigency, and the Court went on to say that: "[n]othing in our Jackson opinion indicates whether we were then aware that not all States require that a defendant affirmatively request counsel before one is appointed; and of course we had no occasion there to decide how the rule we announced would apply to these other States." Id. at 2083-84. The Court thus concluded that the rule in Jackson was unworkable, because it would either prohibit police interrogation for those defendants for whom counsel had been automatically appointed without their request or, if limited to the situation presented in Jackson, prohibit a waiver by defendants who had requested counsel, but allow a waiver for defendants for whom counsel had been appointed without their request. Id. at 2084. Four Justices dissented, contending that the rule in Jackson was designed to protect the defendant's Sixth Amendment right to rely on the assistance of counsel, and that "the evidence is overwhelming that Jackson's simple, bright-line rule has done more to advance effective law enforcement than to undermine it." $I d$. at 2097 (Stevens, J., dissenting).

9. Casey, 505 U.S. at 854-55 (citations omitted). In Casey, the Court reaffirmed what it referred to as the "essential holding" of Roe v. Wade, 410 U.S. 113 (1973), that a state cannot prohibit a woman from having an abortion until the pregnancy has reached the stage of viability, and that after that time, the state must allow an abortion when this is necessary to protect the life or health of the woman. Id. As the Court stated in Casey, "[a] decision to overrule Roe's essential holding under the existing circumstances would address error, if error there was, at the cost of both profound and unnecessary damage to the Court's legitimacy, and to the Nation's commitment to the rule of law. It is therefore imperative to adhere to the essence of Roe's original decision, and we do so today."Id. at 869. The holdings of the Court in Casey were contained in the Joint Opinion of Justices O'Connor, Kennedy, and Souter. Id. at 843-44. The Joint Opinion was joined in by Justices Stevens and Blackmun with respect to the Court's refusal to overrule Roe $v$. Wade. Id. at 912. The joint opinion, however, went on to modify that part of Roe dealing with abortion regulation, and to hold that the state could regulate the abortion procedure so long as the regulation did not impose an "undue burden" on the right of a woman to have an abortion. Id. at 920-22. Since four Justices would have overruled Roe in its entirety, the Joint Opinion's "undue burden" test represents the Court's holding on the issue of abortion regulation, as the narrowest ground of agreement among the Justices joining in the majority on this issue. Marks v. United States, 430 U.S. 188, 193 (1977). The significance of Casey, of course, lies in the Court's reaffirmation of the "essential holding" of Roe v. Wade. As the Joint Opinion states: "[t]he woman's right to terminate her pregnancy before viability is the most central principle of Roe $v$. Wade. It is a rule of law and a component of liberty we cannot renounce." Casey, 505 U.S. at 871. 
The primary basis for the Supreme Court's overruling a particular prior decision is that the prior decision was not consistent with other prior decisions or with subsequent decisions in the same area of law, so that the decision is an "outlier" in the line of growth of legal doctrine. This basis for overruling illustrates the consideration of "whether related principles of law have so far developed as to have left the old rule no more than a remnant of abandoned doctrine." ${ }^{10}$ I will use two examples of "outlier" decisions. The first is in the area of Congress' power under the commerce clause to regulate the interstate movement of persons and things across state lines. In The Lottery Case, ${ }^{11}$ the Court held that under the Commerce Clause, Congress could regulate the interstate movement of persons and things across state lines, and so could prohibit the transportation of lotteries across state lines. In a series of subsequent cases, the Court continued to uphold this component of the commerce power, holding that Congress could prohibit, among other things, the interstate transportation of stolen automobiles, ${ }^{12}$ the interstate transportation of a kidnapping victim, ${ }^{13}$ interstate prostitution, ${ }^{14}$ and the interstate sale of goods produced by inmate labor. ${ }^{15}$ However, in its 1918 decision in Hammer v. Dagenhart, ${ }^{16}$ the Court, at a time when it was using the Due Process Clause to restrict power of both the federal government and the states to enact economic regulation, ${ }^{17}$ held that Congress could not use its power under the commerce clause to prohibit the interstate transportation of goods produced by child labor, because the goods themselves were not "harmful." The Court overruled Hammer v. Dagenhart in United States v. Darby,${ }^{18}$ where the Court upheld the power of Congress to prohibit the transportation in interstate commerce of goods that were produced in violation of the federal Fair Labor Standards Act. ${ }^{19}$ In explaining the overruling of Hammer v. Dagenhart, the Court stated as follows:

Hammer v. Dagenhart has not been followed. The distinction on which the decision was rested that Congressional power to prohibit interstate commerce is limited to articles which in

10. Casey, 505 U.S. at 855.

11. 188 U.S. 321 (1903).

12. Brooks v. United States, 267 U.S. 432 (1925).

13. Gooch v. United States, 297 U.S. 124 (1936).

14. Hoke v. United States, 227 U.S. 308 (1913).

15. Kentucky. Whip \& Collar Co. v. Ill. Cent. R.R., 299 U.S. 334 (1937).

16. 247 U.S. 251 (1918).

17. See discussion infra notes $36-41$ and accompanying text.

18. 312 U.S. 100 (1941).

19. 29 U.S.C.A. $\S \S 201-219$ (West 2010) 
themselves have some harmful or deleterious property - a distinction which was novel when made and unsupported by any provision of the Constitution - has long since been abandoned. The thesis of the opinion that the motive of the prohibition or its effect to control in some measure the use or production within the states of the article thus excluded from commerce can operate to deprive the regulation of its constitutional authority has long since ceased to have force. . . . The conclusion is inescapable that Hammer v. Dagenhart was a departure from the principles which have prevailed in the interpretation of the Commerce Clause both before and since the decision and that such vitality, as a precedent, as it then had has long since been exhausted. It should be and now is overruled. ${ }^{20}$

The second example is in the area of individual rights. In Bowers $v$. Hardwick, ${ }^{21}$ the Court in a 5-4 decision, held that a state did not violate the Due Process Clause when it prohibited two consenting adults from engaging in "homosexual sodomy." The decision was somewhat surprising, since it went counter to a line of decisions beginning with Griswold v. Connecticut, ${ }^{22}$ and continuing through Eisenstadt v. Baird, ${ }^{23}$ Roe v. Wade ${ }^{24}$ and Carey v. Population Services International, ${ }^{25}$ that recognized the right of individuals, married and single, to make personal decisions regarding sexual conduct, free from governmental interference. In Lawrence v. Texas, ${ }^{26}$ the Court overruled Bowers v. Hardwick, and held that a Texas law prohibiting as "deviate sexual intercourse," anal or oral sex between same-sex consenting adults violated due process. Justice Kennedy, writing for the Court, strongly criticized the majority opinion in Bowers and pointed out a number of deficiencies in that opinion. ${ }^{27}$ More to the point for present purposes, he said that the Court's subsequent decisions in Planned Parenthood of Southeastern Pennsylvania v. Casey, ${ }^{28}$ where the Court reaffirmed the "essential holding" of Roe v. Wade, and in Romer v. Evans, ${ }^{29}$ where the Court held violative of equal protection a state constitutional provision prohibiting

\footnotetext{
20. 312 U.S. at 116-17 (citations omitted).

21. 478 U.S. $186(1986)$.

22. 381 U.S. 479 (1965).

23. 405 U.S. 438 (1972).

24. 410 U.S. 113.

25. 431 U.S. 678 (1977).

26. 539 U.S. $558(2003)$.

27. Id. at 567-73 (citations omitted).

28. 505 U.S. 833.

29. 517 U.S. 620 (1996).
} 
the inclusion of discrimination on the basis of sexual orientation in the state's anti-discrimination laws, "cast [the Bowers holding] into even more doubt,"30 and that "[t]he foundations of Bowers have sustained serious erosion from our recent decisions in Casey and Romer. ${ }^{\prime 31} \mathrm{He}$ concluded that: "Bowers was not correct when it was decided, and it is not correct today. It ought not to remain binding precedent. Bowers $v$. Hardwick should be and now is overruled." 32

In Lawrence, Justice Kennedy made a very important point about overruling a precedent that recognized a constitutional liberty interest, as would have happened if the Court had overruled Roe in Casey, and overruling a precedent that did not. He stated as follows:

[i]n Casey, we noted that when a court is asked to overrule a precedent recognizing a constitutional liberty interest, individual or societal reliance on the existence of that liberty interest cautions with particular strength against reversing course .... The holding in Bowers, however, has not induced detrimental reliance, comparable to some instances where recognized individual rights are involved. Indeed, there has been no individual or societal reliance on Bowers of the sort that could counsel against overturning its holding once there are compelling reasons to do so. Bowers itself causes uncertainty, for the precedents before and after its issuance contradict its essential holding. ${ }^{33}$

Thus far, looking to the practice of the United States Supreme Court with respect to overruling prior decisions, we may make the following observations. First, the Court generally will not overrule a prior decision on the ground that a majority of the Court as currently constituted believes that the prior decision was wrongly decided. Second, the Court has set out guidelines for the overruling of prior decisions, and has stated that "its judgment is customarily informed by a series of prudential and pragmatic considerations designed to test the consistency of overruling a prior decision with the ideal of the rule of law, and to gauge the respective costs of reaffirming and overruling a prior case. ${ }^{33}$ Third, the

30. Lawrence, 539 U.S. at 573.

31. Id. at 576 .

32. $I d$. at 577 .

33. Id. at 578 (citations omitted). Despite the continuing and intense public controversy over abortion, there is no realistic possibility that the Court, regardless of its composition at a given time, will overrule Roe v. Wade. See Robert A. Sedler, The Supreme Court Will Not Overrule Roe v. Wade, 34 HoFSTRA L. REv. 1207 (2006).

34. Casey, 505 U.S. at 854. 
primary basis for overruling a particular prior decision is that the prior decision was not consistent with other prior decisions or with subsequent decisions in the same area of law, so that the decision is an "outlier" in the line of growth of legal doctrine. ${ }^{35}$

I now want to discuss another aspect of overruling prior decisions. This is where the Court has concluded that over a period of time, a series of prior decisions and the resulting doctrine and precedent that they represent are no longer consistent with conditions prevailing in contemporary American society. In Casey, the Court stated that "only two such decisional lines from the past century presented themselves for examination, and in each instance the result reached by the Court accorded with the principles we apply today."${ }^{36}$

The first example is the line of cases beginning with Lochner $v$. New York, ${ }^{37}$ which, as the Court in Casey stated, "imposed substantive limitations on legislation limiting economic autonomy in favor of health and welfare regulation, adopting in Justice Holmes's view, the theory of laissez-faire. ${ }^{38}$ The Court in Casey went on to say that:

35. See discussion supra notes 10-33, and accompanying text. The Court's very recent and very controversial 5-4 decision in Citizens United v. Fed. Election Comm'n, $130 \mathrm{~S}$. Ct. $876(2010)$, where the Court held that a Congressional ban on corporation and labor union expenditures from general funds for electioneering communications violated the First Amendment, saw the Court overruling its prior decision in Austin v. Mich. Chamber of Commerce, 494 U.S. 652 (1990), and a part of its prior decision in McConnell v. Fed. Election Comm'n, 540 U.S. 93 (2003), which the Citizens United majority said was based on Austin. The primary justification for the overruling of Austin was that the rationale and holding of Austin were inconsistent with prior and subsequent decisions involving the First Amendment rights of corporations and unions to use general funds to influence the political process. Citizens United, 130 S. Ct. at 911-13. The Court also concluded that Austin was undermined by experience since its announcement and that no serious reliance interests were at stake. Id. See also the concurring opinion of Chief Justice Roberts, joined by Justice Alito, emphasizing the Austin was an “'aberration' insofar as it departed from the robust protections we had granted political speech in our earlier cases." Id. at 916-17 (Roberts, J., concurring). The dissenting justices, on the other hand, contended that the Court majority's decision to overrule Austin and McConnell "comes down to nothing more than its disagreement with their results," that "[t]he only relevant thing that has changed since Austin and McConnell is the composition of this Court," and that "[t]oday's ruling strikes at the vitals of stare decisis." Id. at 942-43. (Stevens, J., dissenting). As Citizens United indicates, the members of the Supreme Court can disagree sharply over whether there is a "special justification" for overruling a prior decision, but in the view of the Court majority in that case, a "special justification" had been established for overruling Austin and McConnell.

36. Casey, 505 U.S. at 861.

37. Lochner v. New York, 198 U.S. 45 (1905).

38. Casey, 505 U.S. at 861. 
The Lochner decisions were exemplified by Adkins v. Children's Hospital of District of Columbia ${ }^{39}$ in which this Court held it to be an infringement of constitutionally protected liberty of contract to require the employers of adult women to satisfy minimum wage standards. Fourteen years later, West Coast Hotel Co. v. Parrish, ${ }^{40}$ signaled the demise of Lochner by overruling Adkins. ${ }^{41}$

The Court in Casey concluded as follows:

In the meantime, the Depression had come and, with it, the lesson that seemed unmistakable to most people by 1937 , that the interpretation of constitutional freedom protected in Adkins rested on fundamentally false factual assumptions about the capacity of a relatively unregulated market to satisfy minimal levels of human welfare .... The facts upon which the earlier case had premised a constitutional resolution of social controversy had proven to be untrue, and history's demonstration of their untruth not only justified but required the new choice of constitutional principle that West Coast Hotel announced. ${ }^{42}$

The second example is the line of cases, beginning with Plessy $v$. Ferguson, ${ }^{43}$ where the Court, proceeding on the dubious assumption that state-imposed racial segregation in public facilities did not stamp African-Americans with a "badge of inferiority," held that such segregation was not violative of equal protection. The Court in Casey then noted that "[t]his understanding of the facts and the rule it was stated to justify were repudiated in Brown v. Board of Education, ${ }^{, 44}$ and that " $[\mathrm{t}] \mathrm{he}$ Court in Brown addressed these facts of life by observing that

39. 261 U.S. 525 (1923).

40. 300 U.S. 379 (1937).

41. Casey, 505 U.S. at 861 (citations omitted).

42. Id. at 861-62. As Professor Laurence H. Tribe has observed: "In large measure, however, it was the economic realities of the Depression that graphically undermined Lochner's premises. No longer could it be argued with great conviction that the individual hand of economics was functioning simultaneously to protect individual rights and to produce a social optimum. The legal 'freedom' of contract and property came increasingly to be seen as an illusion, subject as it was to impersonal economic forces. Positive government intervention came to be more widely accepted as essential to individual, family, and community survival, and legal doctrines would henceforth have to operate from that premise." Laurence H. Tribe, AMERICAN CONSTITUTIONAL LAW 1358 (3rd ed. 2000).

43. 163 U.S. 537 (1896).

44. 347 U.S. 483 (1954). 
whatever may have been the understanding in Plessy's time of the power of segregation to stigmatize those who were segregated with a 'badge of inferiority,' it was clear by 1954 that legally sanctioned segregation had just such an effect, to the point that racially separate public educational facilities were deemed inherently unequal." ${ }^{45}$ The Court in Casey concluded as follows:

Society's understanding of the facts upon which a constitutional ruling was sought in 1954 was thus fundamentally different from the basis claimed for the decision in 1896. While we think Plessy was wrong the day it was decided, we must also recognize that the Plessy Court's explanation for its decision was so clearly at odds with the facts apparent to the Court in 1954 that the decision to reexamine Plessy was on this ground alone not only justified but required. ${ }^{46}$

The Court in Casey then summed up the basis for its overruling of these two lines of cases:

West Coast Hotel and Brown each rested on facts, or an understanding of facts, changed from those which furnished the claimed justifications for the earlier constitutional resolutions. Each case was comprehensible as the Court's response to facts that the country could understand, or had come to understand already, but which the Court of an earlier day, as its own declarations disclosed, had not been able to perceive. . . . In constitutional adjudication as elsewhere in life, changed circumstances may impose new obligations, and the thoughtful part of the Nation could accept each decision to overrule a prior case as a response to the Court's constitutional duty. ${ }^{47}$

45. Casey, 505 U.S. at 862-63.

46. Id. at 863 (internal citation omitted) (citing Plessy, 163 U.S. at 552-64 (Harlan, J., dissenting)). It may also be noted that in the years leading up to Brown, the "separate but equal" doctrine was eroded to some extent by the Court's decisions in Sweat v. Painter, 340 U.S. 846 (1950), holding that "separate but equal" could not be applied to law schools, and Missouri ex rel Gaines v. Canada, 305 U.S. 337 (1938), holding that the state was required to provide graduate and professional schools for African-Americans within the state. The Court's concern with invalidating racial discrimination against African-Americans is also reflected in decisions such as Shelley v. Kramer, 334 U.S. 1 (1948), prohibiting the enforcement of racially restrictive covenants, and Morgan $v$. Virginia, 328 U.S. 373 (1946), invalidating state-imposed segregation on interstate busses as an undue burden on interstate commerce.

47. Casey, 505 U.S. at 863-64. 
We have seen then that while the U.S. Supreme Court sometimes overrules its prior decisions, it has required a special justification for so doing and has established a series of prudential and pragmatic considerations in support of such justification. Furthermore, in only two situations has the Court overruled a line of cases on the ground that the decisions in those cases were inconsistent with changing conditions and values in contemporary American society.

\section{PRior Decisions AND the DeVelopment of The COMMON LAW}

We rely on the courts of each state to develop the common law of that state. As I have explained more fully elsewhere, in developing the common law, the courts must take into account policy considerations, or as I have put it, judicial policymaking is an integral part of the court's function in developing the common law of the state. ${ }^{48}$ Once a state court renders a decision in the process of developing the common law of that state, that decision, like other decisions of the state court, should be given stare decisis effect unless a special justification can be shown for overruling that decision.

At the same time, the common law must evolve, and the rules of the common law must take into account the changed conditions prevailing in American society at a given time. As conditions prevailing in American society change, it follows that the courts may see the necessity of making changes in the common law of the state to reflect these changed conditions. The changes in the common law should take place only over a period of time, and each change should be supported by a strong justification.

Changing the common law to reflect changing conditions in contemporary American society is illustrated by the decisions of the Michigan Supreme Court, over approximately a thirty-year period beginning in the middle of the twentieth century, which expanded significantly the scope of tort liability in Michigan. The change in the common law expanding the scope of tort liability was a change away from the liability-limiting rules of the late nineteenth century that were promulgated in the wake of the Industrial Revolution to protect the newly-emerging industries. The general principles of the common law imposed liability for negligence based on the three elements of breach of duty, causation, and harm. The courts at that time, however, grafted on to these general principles liability-limiting rules, such as assumption of risk, contributory negligence, and the fellow servant doctrine, all of

48. See generally, Robert A. Sedler, The Constitution, The Courts and the Common Law, 53 WAYNE LAW REV. 153 (2007). 
which had the effect of denying recovery to workers and other victims of industrial accidents. ${ }^{49}$ In retrospect, it can be contended that these liability-limiting rules reflected conditions existing at that time in the Nation's history, and it is at least arguable that these rules served important policy interests at that time.

As American industries became more established, the need for liability-limiting common law rules became considerably diminished. The first response to these changing conditions was a legislative one. In Michigan, as elsewhere, the legislature dramatically changed the common law rules limiting the employer's liability for employee workrelated injuries by the enactment of a worker's compensation law in 1912 , and in so doing, abolished the defenses of contributory negligence, assumption of risk, and the fellow servant rule that had been used to deny recovery by the employee against the employer for work-related injuries. ${ }^{50}$

The courts were slow to follow with changes in the common law. However, beginning in the middle of the twentieth century, the courts started to make changes in the common law to reflect changed conditions in contemporary American society. In approximately a thirty-year period, the Michigan Supreme Court, like many other state courts, changed the common law rules to expand significantly the scope of tort liability. In so doing, the Court recognized its responsibility to develop the common law of the state, emphasizing that "rules created by the court could be altered by the court," and that the court had a "corrective responsibility" when dealing with judge-made law. ${ }^{51}$ During this period, the Michigan Supreme Court made the following changes in Michigan tort law: the Court eliminated the imputed negligence doctrine, under which the driver's negligence was imputed to the passenger in the passenger's suit against a third party ${ }^{52}$ it eliminated charitable immunity as a defense to a tort action; ${ }^{53}$ it held that a wife could maintain a tort

49. In speaking of the origins of the contributory negligence doctrine, for example, the late Michigan Supreme Court Justice G. Mennen Williams observed: "Basically the commentators have agreed that the most plausible explanation for the origin of the doctrine was the period of individualism and rapid development known as the Industrial Revolution. The policy, it was said, was designed to protect infant industries 'from oversympathetic juries who regarded these corporation defendants as intruders, as well as immensely rich." Kirby v. Larson, 400 Mich. 585, 620, 256 N.W.2d 400, 417 (1977).

50. See Felgner v. Anderson, 375 Mich. 23, 44 , 133 N.W.2d 136, 147 (1964).

51. Placek v. City of Sterling Heights, 405 Mich. 638, 657, 275 N.W.2d 511, 517 (1979).

52. Bricker v. Green, 313 Mich. 218, 21 N.W.2d 105 (1946).

53. Parker v. Port Huron Hosp., 361 Mich. 1, 105 N.W.2d 1 (1960). 
action for loss of her husband's consortium; $;{ }^{54}$ it abrogated the defense of assumption of risk, ${ }^{55}$ it held that there could be recovery for pre-natal injuries; ${ }^{56}$ and finally, it abolished contributory negligence in favor of a comparative negligence approach. ${ }^{57}$

In rendering these decisions, which had the effect of overruling decisions of a much earlier time, the Michigan Supreme Court emphasized how conditions had changed in contemporary American society. For example, with respect to the elimination of the imputed negligence doctrine, the Court stated as follows:

Ever since 1872 we have adhered to the imputed negligence rule. We have recognized from time to time the changes brought about by the innovation of science and engineering, and we have carefully considered at much length the implications of the rule, its application, and the effect of its abandonment. As a result of our study and observations we are convinced that in the long run the application of the rule is more harmful than helpful and results in more injustice than it prevents. ${ }^{58}$

The Court's justifications for eliminating charitable immunity as a defense to tort liability were that charitable immunity itself was an exception to the general rule of tort liability, that the historical basis for the rule was that it was deemed to advance a sound public policy, and that the reasons for and the consequences of charitable immunity are "not convincing in the light of modern conditions, both in the law and in philanthropy." 59 In modern times insurance against tort liability was available to charities, so there was no danger of dissipation of the charity's assets if it was subjected to tort liability. Weighted against these facts was the cost of the victim's bearing the full burden of the injury, so that the arguments for sustaining charitable immunity "no longer have, if they ever had compelling effect."

The Court's holding that a wife could now maintain an action for the loss of her husband's consortium was premised on modern principles of equality of the sexes in the marriage relationship, so that the common law rule allowing a husband to recover for the loss of his wife's

54. Montgomery v. Stephan, 359 Mich. 33, 101 N.W.2d 227 (1960).

55. Felgner, 375 Mich. 23, 133 N.W.2d 136.

56. Womack v. Buchhorn, 384 Mich. 718, 187 N.W.2d 218 (1971).

57. Placek, 405 Mich. 638, 275 N.W.2d 511 (1979).

58. Bricker, 313 Mich. at 235, 21 N.W.2d at 111.

59. Parker, 361 Mich. at 16, 105 N.W.2d at 9 .

60. Id. at $18-19,105$ N.W.2d at 10. 
consortium was extended in the "line of growth" to allow a wife to recover for the loss of her husband's consortium as well. ${ }^{61}$ Its holding that a child could recover for pre-natal injuries, the Court recognized that "[l]egal philosophy and precedent have moved in response to scientific and popular knowledge," and concluded that "Michigan should recognize what present day science, philosophy and the great weight of the law in this country consider the better and the sound rule." Court's abrogation of the defense of assumption of risk emphasized that the historical basis of the doctrine was to protect the employer from liability to the employee for work-related injuries, so that the utility of the doctrine was drastically restricted by the adoption of a worker's compensation law, ${ }^{63}$ and that the doctrine served only to relieve a defendant of the legal consequences of his own negligent acts on the theory that the plaintiff assumed the risk of injuries from such negligent acts. $^{64}$

Perhaps the most extensive discussion of changing the law to reflect changing conditions was in Placek v. City of Sterling Heights, ${ }^{65}$ where the Court abolished contributory negligence as a complete bar in favor of a comparative negligence approach. The Court began by noting:

[t]here is little dispute among legal commentators that the doctrine of contributory negligence has caused substantial

61. As the Court stated in Montgomery: "The Married Women's Acts and common constitutional provisions have wrought a revolutionary change. Legally, today the wife stands on a par with her husband. Factually, as we well know, her position is no less than that of an equal partner. The precedents of the older cases are not valid precedents. They are violative of women's statutory rights and constitutional safeguards. They are out of harmony with the conditions of modern society. They do violence to our convictions and our principles. We reject their applicability. The reasons for the old rule no longer obtaining, the rule falls with it. The obstacles to the wife's action were judge-invented and they are herewith judge-destroyed." Stephan, 359 Mich. at 49, 101 N.W.2d at 234. In light of post-Montgomery decisions of the U.S. Supreme Court, for a state to allow a husband to maintain an action for loss of his wife's consortium, but to deny the same cause of action to the wife for loss of her husband's consortium, would clearly violate the Fourteenth Amendment's equal protection clause. See, e.g., Frontiero v. Richardson, 411 U.S. 677 (1973) (providing married men in military service with an automatic "dependency allowance," but requiring married women in military service to prove the actual dependency of their husbands in order to qualify for "dependency allowance" is unconstitutional).

62. Womack, 384 Mich. at 720, 724, 187 N.W.2d at 219-20, 222.

63. Felgner, 375 Mich. at 41,133 N.W.2d at 146.

64. Id. at 44,133 N.W.2d at 147. The application of the doctrine also created confusion with the doctrine of contributory negligence and with the question of whether the defendant's activity amounted to negligence in the first place.

65. See Placek, 405 Mich. at 657, 275 N.W.2d at 517. 
injustice since it was first invoked in England in 1809, and that it had been discarded in almost every common law jurisdiction outside of the United States and by that time had been rejected in favor of some form of comparative negligence in the clear majority of American states. ${ }^{66}$ The Court next emphasized that in all the other cases discussed above, the Court had exercised a "corrective responsibility when dealing with judge-made law. ${ }^{67}$

Then the Court dealt with the question of whether it was appropriate for the courts rather than the legislature to change the common law rule of contributory negligence in favor of a rule of comparative negligence. ${ }^{68}$ Here the Court rejected the oft-asserted claim that the legislature had the superior power of investigating important policy and making an informed choice among available alternatives. ${ }^{69}$ It pointed out that the same quantitative data on the impact of comparative negligence on insurance rates and on the processing of claims by settlement that was available to the legislature was likewise available to judges. ${ }^{70}$ In addition, the claim that the legislature could enact change and simultaneously anticipate the numerous details and collateral issues was refuted by the fact that almost all comparative negligence statutes were brief and assigned the courts the responsibility of dealing with ancillary questions. $^{71}$ Finally, the courts could deal with issues of planning and insurability by making decisions that changed the common law prospective in application. ${ }^{72}$ Thus, the Court concluded that the courts were "certainly in as good, if not better, a position to evaluate the need for change and to fashion that change."

66. Id. at 652,275 N.W.2d at 513 .

67. $l d$. at 657,275 N.W.2d at 517.

68. Id.

69. Id.

70. Placek, 405 Mich. at 657,275 N.W.2d at 517.

71. Id.

72. Id.

73. Id. at 658,275 N.W.2d at 518 . The Court in Placek adopted a pure comparative negligence approach, under which the plaintiff's recovery is reduced by the percentage of the plaintiff's own fault so that, for example, a plaintiff who is deemed sixty percent at fault and who suffered 100,000 dollars in damages still will recover 40,000 dollars. Id. at 660-62, 275 N.W.2d at 519-20. The Court noted that the Michigan Legislature "has the power to reinstate contributory negligence or to modify this rule of comparative negligence." Id. at 662, n.12. In 1995, as part of the process of tort reform, the Michigan Legislature provided for comparative negligence by statute, and while retaining pure comparative negligence with respect to economic damages, it prohibited recovery for non-economic damages where the plaintiff's proportion of fault was greater than the aggregate fault of the other person or persons. МICH. COMP. LAwS ANN. $\S 600.2959$ (West $2000 \&$ Supp. 2007). 
The Michigan Supreme Court's series of decisions changing the common law to expand significantly the scope of tort liability in order to reflect changing conditions in American society is similar to the two situations discussed by the U.S. Supreme Court in Casey, where that Court concluded that over a period of time, a series of prior decisions and the resulting doctrine and precedent they represented were no longer consistent with conditions prevailing in contemporary American society. One situation, it will be recalled, was the line of cases beginning with Lochner v. New York, ${ }^{74}$ where the Court had "imposed substantive limitations on legislation limiting economic autonomy in favor of health and welfare regulation, adopting, in Justice Holmes's view, the theory of laissez-faire." ${ }^{\text {"75 }}$ The other situation was the line of cases, beginning with Plessy v. Ferguson, ${ }^{76}$ where the Court, proceeding on the dubious assumption that state-imposed segregation in public facilities did not stamp African-Americans with a "badge of inferiority," held that such segregation was not violative of equal protection. In overruling these two lines of cases, the Court in Casey stated as follows:

West Coast Hotel and Brown each rested on facts, or an understanding of facts, changed from those which furnished the claimed justifications for the earlier constitutional resolutions. Each case was comprehensible as the Court's response to facts that the country could understand, or had come to understand already, but which the Court of an earlier day, as its own declarations disclosed, had not been able to perceive. . . . In constitutional adjudication as elsewhere in life, changed circumstances may impose new obligations, and the thoughtful part of the Nation could accept each decision to overrule a prior case as a response to the Court's constitutional duty. ${ }^{77}$

As constitutional law must change to reflect changing conditions and changing values, so must the common law. The Michigan Supreme Court's series of decisions changing the common law to expand significantly the scope of tort liability to reflect changing conditions and changing values in contemporary society, like the decisions of the United States Supreme Court in West Coast Hotel and Brown, does not in any way undercut the principle of stare decisis. Constitutional law and the common law are not static, and as conditions change, constitutional law

\footnotetext{
74. See Lochner, 198 U.S. 45.

75. See Casey, 505 U.S. 861.

76. See Plessy, 163 U.S. 537.

77. Casey, 505 U.S. at 863-64.
} 
and the common law must change with them. But absent the Courts' promulgating a change in the law to reflect changed conditions, the principle of stare decisis demands that the Courts follow past decisions unless there is a special justification for overruling them.

\section{THE ABANDONMENT OF STARE DeCisis by THE MiChigan SUPREME COURT}

As stated above, the principle of stare decisis demands that a court follow past decisions unless there is a special justification for overruling them. Adherence to the principle of stare decisis does not permit a court to overrule past decisions simply because a majority of the court as constituted at a given point in time believes that a past decision was wrongly decided. As the United States Supreme Court has emphasized, the Court should not overrule prior decisions due to a "present doctrinal disposition to come out differently from an [earlier] Court," and that " $[t]$ o overrule prior law for no other reason than that would run counter to the view repeated in our cases, that a decision to overrule should rest on some special reason over and above the belief that a prior case was wrongly decided."${ }^{, 78}$

However, in the last decade or so, this is exactly what the Michigan Supreme Court has done. Beginning in 1999, a new Michigan Supreme Court majority, consisting of Justices Taylor, Corrigan, Markman, and Young, ${ }^{79}$ has expressly overruled by my count thirty-eight cases, some no more than a few years old. ${ }^{80}$ In a number of the cases the Court majority was joined by Justice Weaver, although in more recent years Justice Weaver has disassociated herself from the Court majority and has dissented from the overrulings. Justices Cavanagh and Kelly have usually dissented from the overrulings. This extraordinary number of overrulings has been brought about by an unprecedented change in the

78. Id. at 864 .

79. Three of these Justices were initially appointed by former Governor John Engler and subsequently elected. Justice Taylor was appointed by Governor Engler in 1997 and elected in 1998 and again in 2000. Justice Markman was appointed by Governor Engler in 1999 and elected in 2000 and again in 2004. Justice Young was appointed by Governor Engler in 1999 and elected in 2002. Justice Corrigan was elected in 1998 and again in 2006. At the time of her election, she was the Chief Judge of the Michigan Court of Appeals, to which she had initially been appointed by Governor Engler. In the 2008 election, Justice Taylor, at that time the Chief Justice of the Court, was defeated and replaced on the Court by current Justice Diane Hathaway.

80. I consider four of these rulings to be non-ideological overnulings in the sense that all of the Justices concurred in the decision to overrule. See infra note 143. 
meaning of stare decisis by the Court majority, ${ }^{81}$ a change in the meaning of stare decisis that is completely inconsistent with the meaning of stare decisis as set forth by the U.S. Supreme Court, and to the best of my knowledge, completely inconsistent with the meaning of stare decisis as applied by all of the other American state courts. ${ }^{82}$

Under the approach to stare decisis taken by the Michigan Supreme Court majority during this time, there is no need for any special justification for overruling a prior decision. Unlike the approach to stare decisis taken by the U.S. Supreme Court, where the Court's judgment to overrule a prior case "is customarily informed by a series of prudential and pragmatic considerations designed to test the consistency of overruling a prior decision with the ideal of the rule of law, and to gauge the respective costs of reaffirming and overruling a prior case,, 83 the approach of the Michigan Supreme Court during this period has been to overrule a prior decision solely because the Court majority has concluded that the prior case was wrongly decided. The Court majority has stated that this is the first question it considers, and that once it concludes that the prior case was wrongly decided, "the Court must proceed to examine the effects of overruling, including most importantly the effect on reliance interests and whether overruling would work an undue hardship because of that reliance." ${ }^{\prime 4}$ However, the Court majority has never refused to overrule a case on the ground that "overruling would work an undue hardship because of that reliance. ${ }^{, 85}$ So, realistically, this purported consideration has played no role at all in the Court majority's

81. The extraordinary number of overrulings in the period 1999-2008 contrasts sharply with the number of overrulings in the preceding ten year period, 1989-1998. My research has disclosed only eight overrulings during this time, three of which occurred in 1998. See discussion infra notes 139-142 and accompanying text.

82. One important exception may be the Montana Supreme Court, which has been criticized for overruling far more cases than the Michigan Supreme Court in the last decade. See generally Jeffrey T. Renz, Stare Decisis In Montana, 65 MONT. L. REV. 41 (2004). However, the Montana overrulings seem to be attributable to an extremely lenient view of stare decisis. Id. at 87 . This is in contrast to the Michigan Supreme Court, which seems to have based its overrulings completely on ideological grounds. See infra notes 78-81 and accompanying footnotes.

83. Casey, 505 U.S. at 854 . These considerations include: "whether the rule has proven to be intolerable simply in defying practical workability; whether the rule is subject to a kind of reliance that would lend a special hardship to the consequences of overruling and lend inequity to the cost of repudiation; whether related principles of law have so far developed as to have left the old rule no more than a remnant of abandoned doctrine; or whether facts have so changed, or come to be seen so differently, as to have robbed the old rule of significant application or justification." Id. (citations omitted).

84. Robinson v. City of Detroit, 462 Mich. 439, 466, 613 N.W.2d 307, 321 (2000).

85. Id. at 460,613 N.W. 2 d at 321 . 
overruling of a prior decision. ${ }^{86}$ The only realistic consideration has been the Court majority's conclusion that the prior case was wrongly decided. ${ }^{87}$

The largest number of the overruling decisions has involved interpretation of statutes. Here, the Court majority insisted that the courts must follow the "plain meaning" of a statute (as the Court majority defined the "plain meaning"), ${ }^{88}$ and it has justified its rejection of stare decisis in this context on the ground that the values furthered by stare decisis "are also furthered by judicial decisions that are neutrally grounded in the language of the law, by a legal regime in which the public may read the plain words of its law and have confidence that such words mean what they say and are not the exclusive province of lawyers." ${ }^{.89}$ The Court majority has also stated that when a court has

86. Where the Court majority found that there had been reliance on the overruled decision, it directed that the new decision only be applied prospectively or be given limited retroactive application, applying to cases in which the issue was raised and preserved. See Pohutski v. City of Allen Park, 465 Mich. 675, 641 N.W.2d 219 (2002); Gladych v. New Family Homes, Inc., 468 Mich. 594, 664 N.W.2d 705 (2003). At times, the Court majority has also stated that considerations relevant to overruling include "practical workability" and "whether changes in the law or facts no longer justify the questioned decision," Pohutski 465 Mich. at 694, 641 N.W.2d at 231-32, but to the extent that the Court has invoked these considerations, it has been only in a limited way and primarily to justify the conclusion that the prior case was wrongly decided. At other times, the Court has stated that it only uses a two-part test: "[b]efore this Court overrules a decision, we must make two inquiries: (a) whether the earlier decision was wrongly decided, and (b) whether overnuling such decision would work and undue hardship because of reliance interests or expectations that have arisen." Robertson v. DaimlerChrysler Corp., 465 Mich. 732, 757, 641 N.W.2d 567, 581 (2002) (citing Robinson, 462 Mich. 439, 613 N.W.2d 307).

87. As now Chief Justice Marilyn Kelly stated in one of her numerous dissents from the overruling decisions: "[ $t]$ he predictable result of the majority's current approach is that once a party meets its initial burden of demonstrating that a prior decision was wrong, the precedent is overturned." People v. Gardner, 482 Mich. 41, 83, 753 N.W.2d 78, 102-03 (2008) (Kelly, J., dissenting).

88. Chief Justice Kelly strongly disagrees with the Court majority's approach to "plain meaning," and has contended that the Court majority has never found a statute to be ambiguous, so as to require interpretation by the Court. See Marilyn Kelly \& John Postulka, The Fatal Weakness in the Michigan Supreme Court's Majority's Textualist Approach to Statutory Construction, 10 T.M. COOLEY J. PraC. \& Clinical L. 287 (2008).

89. Robertson, 465 Mich. at 757,641 N.W.2d at 581 (citing Robinson, 462 Mich. 439,613 N.W.2d 307. The Court majority has also rejected any notion of "legislative acquiescence" in the sense that where the Court has interpreted a statute and the legislature has not amended it to change the Court's interpretation, the legislature is deemed to have "acquiesced" in that interpretation. Id. As it stated in Robertson: "[s]uch an 'acquiescence' argument has been squarely rejected by this Court because it misunderstands the legislative process, and because it would accord greater weight to the silence of a subsequent Legislature than to the actual product of the Legislature that 
misinterpreted a statute, "[a] subsequent court, rather than holding to the distorted reading because of the doctrine of stare decisis, should overrule the [prior decision]. ${ }^{.90}$ It went on to say:

The reason for this is that the court in distorting the statute was engaged in a form of judicial usurpation that runs counter to the bedrock principle of American constitutionalism, i.e., that the lawmaking power is reposed in the people as reflected in the work of the Legislature, and absent a constitutional violation, the courts have no legitimacy in overruling of nullifying the people's representatives. Moreover, not only does such a compromising by a court of the citizen's ability to rely on a statute have no constitutional warrant, it can gain no higher pedigree as later courts repeat the error. ${ }^{91}$

The problem with this line of reasoning is that it ignores the fact that the earlier decisions were based on the assumedly good faith efforts of the Court at that time to ascertain the meaning of the statutes. The Court in the earlier decisions was applying principles of statutory interpretation, as the Court saw them, and the Court at that time interpreted the statutes differently from the way that the Court majority at a later time thought that they should be interpreted. The Court at an earlier time was not trying in any way to "usurp" or "nullify" the legislative function. To the contrary, the Court at the earlier time was performing the judicial function in interpreting the statute, and when the rhetoric of the later Court majority is stripped away, the Court majority is saying nothing more than that it disagrees with the Court's interpretation of the statutes in the earlier cases. To overrule an earlier decision simply because the Court majority at a later time disagrees with the Court's interpretation of a statute at an earlier time clearly violates the principle of stare decisis. The principle of stare decisis, it may be noted, is no less applicable when the prior decision involved statutory interpretation than when it involved constitutional or common law interpretation. Again, as the U.S. Supreme Court has emphasized, a court should not overrule prior decisions due to a "present doctrinal disposition to come out differently from the [earlier] Court," and that "[t]o overrule prior law for

enacted a law." Id. at 760,641 N.W.2d at 582, n.15. While I would not dispute this proposition, I would also submit that under the principle of stare decisis, a court should "acquiesce" in its own prior interpretation of a statute unless there is a "special justification" for overnuling that prior interpretation.

90. Robinson, 462 Mich. at 467,613 N.W.2d at 321.

91. Id. at 467-68, 613 N.W.2d at 321-22. 
no other reason than that would run counter to the view repeated in our cases, that a decision to overrule should rest on some special reason over and above the belief that a prior case was wrongly decided." ${ }^{.92}$

In any event, there is a long list of decisions by the Court majority, twenty-six by my count, overruling prior decisions interpreting a statute on the ground that the earlier decision ignored the "plain meaning" of the statute. The holdings of the overruling decisions in civil cases are as follows. Under the operation of a motor vehicle exception to governmental tort immunity in MCL Section 691.1405, where the police cars did not hit the fleeing vehicle, or physically force it off the road, the injuries of innocent persons in the passenger vehicle did not result from the operation of the police cars; an officer's decision to pursue does not constitute the negligent operation of a motor vehicle. ${ }^{93}$ The "highway exception" to governmental tort immunity under MCL Section 691.1402(1) does not impose a duty to install, maintain, repair, or improve traffic control devices, including traffic signs. ${ }^{94} \mathrm{~A}$ jail inmate is not a "member of the public" within the meaning of the public building exception to governmental immunity under MCL Section $691.1406 .{ }^{95}$ In order to satisfy the mental disability requirements of the worker's compensation law, MCL Section 418.301(2), a worker must demonstrate that there had been an actual employment event leading to the employee's mental disability and that the worker's perception of apprehension of the event was grounded in fact or reality, not in the

92. Casey, 505 U.S. at 864. In her dissenting opinion in Robinson, now Chief Justice Marilyn Kelly stated as follows:

The majority's decision to overrule three distinct, well-reasoned lines of cases is unparalleled. I am not alone in adjudging such casual regard for prior Michigan jurisprudence and the principles of stare decisis disheartening and unwarranted. One might perceive from the majority's review of the issues in Fiser, Rogers, and Dedes, that the outcome of this case turns simply on who had the better argument. It does not. The majorities' positions in those cases became the law of the land. As a consequence, the real question in this case is whether today's majority has justified its decision with the extraordinary showing that this Court has consistently demanded before overruling precedent. In my view, the majority has not come close to making such a showing. Robinson, 462 Mich. at 475-76, 613 N.W.2d at 325 (Kelly, J., dissenting).

93. Robinson, 462 Mich. 439, 613 N.W.2d 307 (overruling Fiser v. Ann Arbor, 417 Mich. 461, 339 N.W.2d 413 (1983), and Rogers v. Detroit, 457 Mich. 125, 579 N.W.2d $840(1998))$.

94. Nawrocki v. Macomb County Road Comm'n, 463 Mich. 143, 615 N.W.2d 702 (2000) (overruling Pick v. Szymczak, 451 Mich. 607, 548 N.W.2d 603 (1996)).

95. Brown v. Genesee County Bd. of Comm'rs, 464 Mich. 430, 628 N.W.2d 471 (2001) (overruling Green v. Dep't of Corrections, 386 Mich. 459, 192 N.W.2d 491 (1971)). 
delusion or imagination of an impaired mind. ${ }^{96}$ The governmental immunity law, MCL Section 691.1407, did not contain a trespassnuisance exception to governmental immunity. ${ }^{97}$ Under MCL Section 418.301(4), "disability" could not be read as describing the situation where an employee was unable to perform a particular job because of a work-related injury, but was moved to another job and suffered no reduction in wage earning capacity ${ }^{98}$ A person who is not physically inside a vehicle, such as a person who was standing six inches outside the vehicle when another vehicle struck him, is not an "occupant" of the vehicle for purposes of the personal protection insurance benefits of the no-fault law, MCL Section 500.3106(1)(c). ${ }^{99}$ Harassment based on gender that was not sexual in nature did not constitute sexual harassment under the Civil Rights Act, MCL Section 37.2013(i). ${ }^{100}$ Under MCL Section 600.805 , where the employee filed a complaint for a workrelated injury within the limitations period, but did not complete any of the other actions required to toll the statute, the limitations period continued to run, and in this case expired before the employee served the employer. ${ }^{101}$ Under the statute of limitations provisions of MCL Section 600.5805 , the statute runs from the time of the alleged wrong, and there is no continuing violations exception to the running of the statute. ${ }^{102}$ There can be no judicial tolling of the "one-year back" limitation of MCL Section 500.3145(1) for recovering no-fault personal protection insurance benefits. ${ }^{103}$ Under MCL Section 600.5805 , where the employee alleged that discriminatory acts occurred, causing her to submit her resignation, the claims accrued at the time of the alleged misconduct and

96. Robertson, 465 Mich. 732, 641 N.W.2d 567 (overruling Gardner v. Van Buren Pub. Sch., 445 Mich. 23, 517 N.W.2d 1 (1994)).

97. Pohutski v. City of Allen Park, 465 Mich. 675, 641 N.W.2d 219 (2002) (overruling Hadfield v. Oakland County Drain Comm'n, 430 Mich. 139, 422 N.W.2d 205 (1988)).

98. Sington v. Chrysler Corp., 467 Mich. 144, 648 N.W.2d 624 (2002) (overruling Haske v. Transp. Leasing, Inc., 455 Mich. 628, 566 N.W.2d 896 (1997)).

99. Rednour v. Hastings Mut. Ins. Co., 468 Mich. 241, 661 N.W2d 562 (2003) (overruling Nickerson v. Citizens Mut. Ins. Co., 393 Mich. 324, 224 N.W.2d 896 (1975)).

100. Haynie v. State, 468 Mich. 302, 664 N.W.2d 129 (2003) (overruling Koester v. City of Novi, 458 Mich. 1, 580 N.W.2d 835 (1998)).

101. Gladych v. New Family Homes, Inc., 468 Mich. 594, 664 N.W.2d 705 (2003) (overruling Buscaino v. Rhodes, 385 Mich. 474, 189 N.W.2d 202 (1971)).

102. Garg v. Macomb County Cmty. Mental Health Serv., 472 Mich. 263, 696 N.W.2d 646 (2005) (overruling Sumner v. Goodyear Tire \& Rubber Co., 427 Mich. 505, 398 N.W.2d $368(1986))$.

103. Devillers v. Auto Club Ins. Ass'n, 473 Mich. 562, 702 N.W.2d 539 (2005) (overruling Lewis v. Detroit Auto. Inter-Ins. Exch., 426 Mich. 93, 393 N.W.2d 167 (1986)). 
not on the employee's last day of work. ${ }^{104}$ The highway exception to governmental immunity under MCL Section 691.1402(1) does not include the shoulder of a highway. ${ }^{105}$ The term "proximate cause" in MCL Section 418.375(2) means that the work-related injury must be the sole "proximate cause," which is the one most immediate, efficient, and direct cause of the injury or damage. ${ }^{106}$ Under MCR Section 2.504(B)(3), the dismissal of claims of negligence against one party on statute of limitations grounds is an adjudication on the merits and prohibits the plaintiff from proceeding with vicarious liability claims against other defendants. ${ }^{107}$ The failure to comply with the 120 -day notice provision for the defective highway exception to governmental immunity under MCL 691.1404(1) is an absolute bar to recovery without any need for a showing of actual prejudice to the governmental agency. ${ }^{108}$ In order for the Michigan Workers' Compensation Act, MCL Section 418.845, to apply, the injured employee must be a resident of Michigan at the time of the injury, and the contract of hire must have been made in Michigan. ${ }^{109}$ The public building exception to governmental immunity under MCL Section 691.1406 does not include a claim of defective design. ${ }^{110}$ Since MCL Section 600.5805, providing a three year period of limitation for actions to recover for death of a person or injury to person or property, does not provide that the period of limitation is tolled until the plaintiff could have reasonably discovered the elements of a cause of action, the

104. Joliet v. Pitoniak, 475 Mich. 30, 715 N.W.2d 60 (2006) (overruling Jacobson v. Parda Fed. Credit Union, 457 Mich. 318, 577 N.W.2d 881 (1998)).

105. Grimes v. Michigan Dep't of Transp., 475 Mich. 72, 715 N.W.2d 275 (2006) (overruling Gregg v. State Highway Dep't, 435 Mich. 307, 458 N.W.2d 619 (1990)).

106. Paige v. City of Sterling Heights, 476 Mich. 495, 720 N.W.2d 219 (2006) (overruling Hagerman v. Gencorp Auto., 457 Mich. 720, 579 N.W.2d 347 (1998)).

107. Al-Shimmari v. Detroit Med. Ctr., 477 Mich. 280, 731 N.W.2d 29 (2007) (overruling Rogers v. Colonial Fed. Savings and Loan Ass'n, 405 Mich. 607, 275 N.W.2d 499 (1979)).

108. Rowland v. Washtenaw County Road Comm'n, 477 Mich. 197, 731 N.W.2d 41 (2007) (overruling Hobbs v. Michigan State Highway Dep't, 398 Mich. 90, 247 N.W.2d 754 (1976), and Brown v. Mainstee County Road Comm'n, 452 Mich. 354, 550 N.W.2d $215(1996))$.

109. Karaczewski v. Farbman, Stein \& Co., 478 Mich. 28, 732 N.W.2d 56 (2007) (overruling Boyd v. W G Wade Shows, 443 Mich. 515, 505 N.W. 2d 544 (1993)). In Bezeau v. Palace Sports \& Entertainment, the Michigan Supreme Court overruled the part of Karaczewski giving retroactive effect to the decision and held that the decision in Karaczewski would not apply to "claims based on injuries that occurred on or before the date this Court decided Karaczewski, as long as the claim had not already reached final resolution in the court system." Bezeau v. Palace Sports \& Entertainment, No. 137500, 2010 WL 3037781, at *6 (Mich. July 31, 2010).

110. Renny v. Michigan Dep't of Transp., 478 Mich. 490, 734 N.W.2d 518 (2007) (overruling Bush v. Oscoda Area Sch., 405 Mich. 716, 275 N.W.2d 268 (1979)). 
courts cannot extend the period of limitation under the common law discovery rule. ${ }^{111}$ The motor vehicle exception to governmental tort immunity, MCL 691.1405, did not waive governmental immunity for a loss-of-consortium claim against a governmental agency. ${ }^{12}$

The holdings of the statutory interpretation overruling decisions in the criminal cases are as follows. Under the harmless error rule of MCL Section 769.26, the defendant has the burden of proving that it was "more probable than not that the error was outcome determinative" rather than the prosecution having the burden of proving that it was "highly probable that the error did not contribute to the verdict." 113 Under MCL Section 768.32(1), a requested instruction on a lesser included offense is proper only if the charged greater offense requires the jury to find a disputed factual element that is not part of the lesser included offense and a rational view of the evidence would support it. ${ }^{114}$ Under the aiding and abetting law, MCL Section 767.39, the proper standard for establishing a felony-firearm violation is whether the defendant's words or deeds procured, counseled, aided or abetted another person to carry or have in his possession a firearm during the commission or attempted commission of a felony-firearm offense. ${ }^{115}$ Under MCL Section 257.625(4), it is only necessary to show that the victim's death was caused by the operation of the vehicle while the driver was intoxicated, and it is not necessary to show that the intoxicated operation of the vehicle was the cause of the victim's death. ${ }^{116}$ The plain language rule, when applied as instructed by MRE 1101(b)(1) and MRE 104(a), allowed the court to consider a statement sought to be shown as an excited utterance, along with other evidence to prove the existence of a startling event or condition, to determine its admissibility under MRE 803(2). ${ }^{117}$ Under Michigan's habitual offender statutes, MCL Section 769.10-13, each separate felony

111. Trentadue v. Gorton, 479 Mich. 378,738 N.W.2d 664 (2007) (overruling Chase v. Sabin, 445 Mich. 190, 516 N.W.2d 60 (1994)).

112. Wesche v. Mecosta County Road Comm'n, 480 Mich. 75, 746 N.W.2d 847 (2008) (overruling Endykiewicz v, State Highway Comm'n, 414 Mich. 377, 324 N.W.2d $755(1982))$.

113. People v. Lukity, 460 Mich. 484, 596 N.W.2d 607 (1999) (overruling People v. Gearns, 457 Mich. 170, 577 N.W.2d 422 (1998)).

114. People v. Cornell, 466 Mich. 335, 646 N.W.2d 127 (2002) (overruling People v. Jones, 395 Mich. 379, 236 N.W.2d 461 (1975) and related cases).

115. People v. Moore, 470 Mich. 56, 679 N.W.2d 41 (2004) (overruling People v. Johnson, 411 Mich. 50, 303 N.W.2d 442 (1981)).

116. People v. Schaefer, 473 Mich. 418, 703 N.W.2d 774 (2005) (overruling People v. Lardie, 452 Mich. 231, 551 N.W.2d 656 (1996)).

117. People v. Barrett, 480 Mich. 125, 747 N.W.2d 797 (2008) (overruling People v. Burton, 433 Mich. 268, 445 N.W.2d 133 (1989)). 
conviction that preceded the sentencing offense counts as a felony even if it did not arise from a separate criminal incident. ${ }^{118}$

Apart from the twenty-six statutory interpretation overruling decisions, the Court majority in two cases limited the scope of its own power under Art. VI, sec. 5 of the Michigan Constitution, which provides that "[t]he supreme court shall by general rules establish, modify, amend and simplify the practice and procedure in all courts of this state." ${ }^{119}$ In one case, the Court majority, overruling in part an earlier decision holding that this provision invalidated any legislation setting forth a rule of evidence, ${ }^{120}$ held that the legislature could enact substantive law in the form of an "evidentiary rule," giving rise to an "evidentiary rule of substantive law," and so could constitutionally prescribe the admissibility of standard of care testimony in medical malpractice actions involving specialists. ${ }^{121}$ In the other case, the Court majority held that Art. VI, sec. 5 of the Michigan Constitution did not give the Michigan Supreme Court the constitutional power to establish a right to a preliminary hearing for persons indicted by a grand jury, ${ }^{122}$ since the right to a preliminary examination is a "matter of public policy for the legislative branch" rather than a "matter of procedure" for the court. ${ }^{123}$

In four other overruling decisions involving civil cases, the Court majority held that in a suit against a governmental agency, the burden is on the plaintiff to plead the avoidance of governmental immunity and that the government cannot waive the defense of governmental immunity; ${ }^{124}$ that in reviewing decisions of the Worker's Compensation Commission, the Court must uphold that decision if supported by any

118. People v. Gardner, 482 Mich. 41, 753 N.W.2d 78 (2008) (overruling People v. Preuss, 436 Mich. 714, 461 N.W.2d 703 (1990), and People v. Stoudemire, 429 Mich. 262, 414 N.W.2d 693 (1987)).

119. МICH. CONST. art. VI, $\S 5$.

120. Perin v. Peuler, 373 Mich. 531, 130 N.W.2d 4 (1964). In that case, the Court held violative of Art. VI, sec. 5, a statute, MCL $\S 257.731$, providing that "No evidence of the conviction of any person for any violation of this chapter or of a local ordinance pertaining to the use of motor vehicles shall be admissible in any court in any civil action." Id.

121. McDougall v. Schanz, 461 Mich. 15, 30-31, 597 N.W.2d 148, 155-56 (1999).

122. MCL $\S 767.1-4$. provides that criminal prosecutions may be initiated either by information or by a grand jury indictment. When a person has been arrested and taken into custody, the statute gives the person a right to a preliminary hearing before the prosecutor issues the information.

123. People v. Glass, 464 Mich. 266, 282-83 627 N.W.2d 261, 269-70 (2001) (overruling People v. Duncan, 388 Mich. 489, 201 N.W.2d 629 (1972), where the Michigan Supreme Court had established the right to a preliminary hearing for grand jury indictees and had issued implementing rules).

124. Mack v. City of Detroit, 467 Mich. 186, 649 N.W.2d 47 (2002) (overruling McCummings v. Hurley Med. Ctr., 433 Mich. 404, 446 N.W.2d 114 (1989)). 
factual basis; ${ }^{125}$ that the courts could not void a contractual limitations period contained in an insurance policy on the ground that the provision was unreasonable; $;^{126}$ and that with respect to the duty of care owed by landowners, a person who entered upon church property for a noncommercial purpose was a public invitee rather than a business visitor. ${ }^{127}$

There were two sets of overruling decisions involving the constitutional rights of persons accused of crime. One set involved claims under the double jeopardy clause of the Michigan Constitution. ${ }^{128}$ The Court majority held that the double jeopardy clause did not prohibit successive prosecutions for the same act where the first prosecution took place in another state. ${ }^{129}$ The Court majority also held that where the defendant had committed a series of crimes with different elements, the defendant could be prosecuted serially for each crime, notwithstanding that the crimes were committed in a single crime spree, ${ }^{130}$ and that convicting and sentencing a defendant both for first degree felony murder and for the predicate felony did not violate the multiple punishment strand of the double jeopardy clause, where each of the offenses of which the defendant was convicted contained an element that the other did not. ${ }^{131}$ The other set involved claims of illegal search and seizure under the Michigan Constitution. ${ }^{132}$ In one case, the Court

125. Mudel v. Great Atlantic and Pacific Tea Co., 462 Mich. 691, 614 N.W.2d 607 (2000) (overruling Goff v. Bilmar-Foods, Inc., 454 Mich. 507, 563 N.W.2d 214 (1997), and Layman v. Newkirk Elec. Assoc., 458 Mich. 494, 581 N.W.2d 244 (1998)).

126. Rory v. Continental Ins. Co., 473 Mich. 457, 703 N.W.2d 23 (2005) (overruling Tom Thomas Org., Inc. v. Reliance Ins. Co., 396 Mich. 588, 242 N.W.2d 396 (1976), and progeny cases).

127. Stitt v. Holland Abundant Life Fellowship, 462 Mich. 591, 614 N.W.2d 88 (2000) (overruling Preston v. Sleziak, 383 Mich. 442, 175 N.W.2d 759 (1970)).

128. MiCh. CONST. art. I, $\S 15$.

129. People v. Davis, 472 Mich. 156, 695 N.W.2d 45 (2005) (overruling People v. Cooper, 398 Mich. 269, 450, 247 N.W.2d 866 (1976)). In People v. Mezy, 453 Mich. 269, 551 N.W.2d 389 (1996), the Court considered overnuling Cooper. Justices Weaver, Boyle and Riley favored overruling Cooper; Chief Justice Brickley, Justices Levin, Cavanagh and Mallet opposed overruling Cooper. All the justices agreed that the case should be remanded for a determination as to the applicability of the statutory double jeopardy provision with respect to controlled substance crimes, MicH. COMP. LAwS ANN. $\S 333.7409$ (West 2010).

130. People v. Nutt, 469 Mich. 565,677 N.W.2d 1 (2004) (overruling People v. White, 390 Mich. 245, 212 N.W.2d 222 (1973)).

131. People v. Ream, 481 Mich. 223, 750 N.W.2d 536 (2008) (overruling People v. Wilder, 411 Mich. 328, 308 N.W.2d 112 (1981)); People v. Smith, 478 Mich. 292, 733 N.W.2d 351 (2007) (overruling People v. Robideau, 419 Mich. 458, 355 N.W.2d 592 (1984)).

132. MICH. CONST. art. I, § 11. 
majority held that the exclusionary rule did not apply to preclude the introduction of evidence obtained under a warrant issued in violation of statutory affidavit requirements. ${ }^{133}$ In the other case, the Court majority held that the smell of fresh marijuana alone, by a person qualified to know the odor, may establish probable cause to search a motor vehicle, pursuant to the motor vehicle exception to the warrant requirement. ${ }^{134}$

There were two non-constitutional criminal cases that resulted in overrulings. In one, the Court majority held that the trial court's failure to instruct the jury on the defense of accident where accident was a central issue in the case, did not require automatic reversal and instead required the defendant to demonstrate that the error affected the outcome of the proceedings. ${ }^{135}$ In the other, it held that when the police violated the chemical testing statute, ${ }^{136}$ by denying the defendant an independent chemical test, the court could not dismiss the case as a remedy for the violation, but was limited to instructing the jury that a violation had occurred. ${ }^{137}$

By my count, in the period from 1999 to 2008, the Michigan Supreme Court overruled thirty-four decisions on ideological grounds. In these cases, a Court majority used its power to overrule decisions to bring about results that favored defendants in civil cases and prosecutors in criminal ones. I believe this record of overrulings on ideological grounds by one state court in a limited time frame is truly extraordinary, and likely unmatched by any other state court. The Court's unrestrained overruling of its prior decisions in the period from 1999-2008 contrasts sharply with the Court's reluctance to do so in the preceding ten-year period from 1989 to 1998, before a new Court majority had been formed as the result of three appointments by former Governor John Engler in 1997 and 1999, the election of these incumbent justices in 1998-2002 and the election of Justice Corrigan in $1998 .{ }^{138}$ My research has disclosed

133. People v. Hawkins, 468 Mich. 488,688 N.W.2d 602 (2003) (overruling People v. Sloan, 450 Mich. 160, 538 N.W.2d 380 (1995), and People v. Sherbine, 421 Mich. 502, 364 N.W.2d 658 (1984)).

134. People v. Kazmierczak, 461 Mich. 411, 605 N.W.2d 667 (2000) (overruling People v. Taylor, 454 Mich. 580, 564 N.W.2d 24 (1997)).

135. People v. Hawthorne, 474 Mich. 174, 713 N.W.2d 724 (2006) (overruling People v. Lester, 406 Mich. 252, 277 N.W.2d 633 (1979)).

136. MICH. COMP. LAWS ANN. $\$ 257.625 a(6)(d)$ (West 2010).

137. People v. Antsey, 476 Mich. 436, 719 N.W.2d 579 (2006) (overruling People v. Koval, 371 Mich. 453, 124 N.W.2d 274 (1963)).

138. There were ten members of the Court during the period from 1989 to 1998. Chief Justice Kelly and Justice Cavanagh of the current court would be classified as liberal in the popular sense, while Justice Weaver of the current court would be classified as conservative at least as of that time. Justices Griffin and Riley would be classified as conservative, Justices Mallett and Levin would be classified as liberal, and Justices 
only eight overrulings of prior decisions during the period from 1989 to 1998. Interestingly enough, three of these overrulings occurred in 1998, all involving criminal cases. ${ }^{139}$ Three of the remaining overrulings were in criminal cases, ${ }^{140}$ one involving a constitutional question ${ }^{141}$ and the other involving the subject matter jurisdiction of a probate court. ${ }^{142}$

Brickley and Boyle would be classified as moderate. Again, I am using these terms as they are used in the popular sense rather than to suggest that there was any sharp ideological division on the Court. There was no such division, and each Justice applied the law as he or she saw it to the issues presented in the particular case.

139. In two of the cases, the overruling was a limited one. In People v. Lemmon, 456 Mich. 625,576 N.W.2d 129 (1998), the Court held that in ruling on a motion for a new trial, the judge could not sit as a thirteenth juror, disagreeing with juror assessment of credibility, but could only grant a new trial if the evidence preponderated so heavily against the verdict so that it would be a miscarriage of justice to allow the verdict to stand. The Court overruled People v. Herbert 444 Mich. 466, 511 N.W.2d 654 (1993), insofar as it appeared to authorize judges to grant new trial motions on the basis of a disagreement with juror assessment of credibility. Justices Cavanagh and Kelly agreed with the decision, but contended that it was not inconsistent with the opinion in Herbert, so that there was no need to overrule any portion of Herbert. In People v. Kaufman, 457 Mich. 266, 577 N.W.2d 466 (1998), the Court held per curiam, with Justices Cavanagh and Kelly concurring only in the result, that the trial court could not rely exclusively on preliminary examination transcripts in ruling on a motion to suppress. The Court overruled People v. Talley, 410 Mich. 378, 301 N.W.2d 809 (1981), insofar as it had been understood to mean that counsel could not agree to have a motion to suppress decided on the record of the preliminary examination. In People v. Graves, 458 Mich. 476, 581 N.W.2d 229 (1998), Justice Taylor joined Justices Weaver, Brickley and Boyle to hold that when a jury is permitted to consider a charge unwarranted by the proofs, a harmless error analysis rather than automatic reversal applies, overruling People v. Vail, 393 Mich. 460, 227 N.W.2d 535 (1975). Chief Justice Mallett and Justices Cavanagh and Kelly dissented, contending that Vail should not be overruled and that in this circumstance there should be an automatic reversal.

140. In People v. Fisher, 442 Mich. 560, 577-88, 503 N.W.2d 50, 57 (1993), the Court, applying the marital privilege statute, MICH. COMP. LAWS ANN. $\S 600.2162$ (West 2010), held that the marital communications privilege did not apply when the spouse was not called to testify, and noted that "[w]e realize that our holding today effectively overrules O'Toole (O'Toole v. Ohio German Fire Insurance Co., 159 Mich. 187, 123 N.W.795 (1909)) and other cited cases to the extent that they can be read as recognizing a broader privilege." Chief Justice Cavanagh and Justice Levin dissented. In People v. Collins, 438 Mich. 8, 475 N.W.2d 684 (1991), the Court overruled People v. Beavers, 393 Mich. 554, 227 N.W.2d 511 (1975), and held that in light of the holding by U.S. Supreme Court in United States v. Caceres, 440 U.S. 741 (1979), and United States v. White, 401 U.S. 745 (1971), that warrantless electronic monitoring of a conversation by one of the conversants did not violate the Fourth Amendment, and that such monitoring did not violate art. I, sec. 11 of the Michigan Constitution. Chief Justice Cavanagh and Justice Levin dissented. In People v. France, 436 Mich. 138, 461 N.W.2d 621 (1990), the Court, overruling Zaitzeff v. Raschke, 387 Mich. 577, 198 N.W.2d 309 (1972) and progeny, held that where a judge communicates with the jury outside of the courtroom and the presence of counsel, automatic reversal is not required, and the test for reversal is any reasonable possibility of prejudice. Justices Levin, Cavanagh and Archer dissented. 
Returning now to the unrestrained overrulings in the period from 1999-2008, when we look to the results of the overruling decisions, we may observe a very significant phenomenon. In every civil case, the result of the overruling of the prior decision was to favor defendants over plaintiffs by limiting liability or making it more difficult for plaintiffs to assert a claim. In every criminal case, the result of the overruling of the prior decision was to favor the prosecution over the defendant and to uphold a conviction against the defendant's statutory or constitutional claim. It may fairly be suggested, therefore, that the Court majority's unprecedented overruling of a large number of prior decisions advanced the Court majority's policy objectives of limiting tort liability and worker's compensation recovery and of making it more difficult for persons charged with crimes to avoid a conviction. This phenomenon seriously calls into question the legitimacy of the Court majority's justification for its abandonment of stare decisis. What has happened in Michigan, pure and simple, is that a majority of the justices on the Michigan Supreme Court have used their power to overrule prior decisions with which they disagreed, in order to make significant changes in Michigan's tort law in favor of defendants over plaintiffs, significant changes in worker's compensation law in favor of employers over workers, and significant changes in criminal law in favor of prosecutors over defendants. ${ }^{143}$ In so doing, the Court majority has led the Michigan Supreme Court to abandon stare decisis. ${ }^{144}$

141. In W.T. Andrew Co., Inc. v. Mid-State Surety Corp., 450 Mich. 655,545 N.W.2d 351 (1996), overruling Weinberg v. University of Michigan Regents, 97 Mich. 246, 56 N.W. 605 (1893), the Court unanimously held that the public works bond statute, MCL $\S 129.201$, could constitutionally be applied to a constitutionally-created entity, such as the University of Michigan.

142. In Hatcher v. Hatcher, 443 Mich. 426439,505 N.W.2d 834, 840 (1993), the Court unanimously held that a probate court's jurisdiction is established when the proceeding is of a class that the court is authorized to adjudicate and the claim stated in the complaint is not clearly frivolous. This being so, the jurisdiction of the probate court can be challenged only on direct appeal and not by way of collateral attack. Although the Court found its earlier decision in Fritts v. Krugh, 354 Mich. 97, 92 N.W.2d 604 (1958), to be distinguishable, it nonetheless decided to overrule Fritts and its progeny.

143. During this period there were four overrulings that may be referred to as nonideological overrulings in the sense that all of the Justices concurred in the decision to overnule. The most important of these cases was County of Wayne v. Hathcock, 471 Mich. 445, 684 N.W.2d 765 (2004), in which the Court overruled its prior decision in Poletown Neighborhood Council v. Detroit, 410 Mich. 616, 304 N.W.2d 455 (1981). Both cases involved an interpretation of Art. X, sec. 2 of the Michigan Constitution, which provides that "private property shall not be taken for public use without just compensation therefore being first made or secured in a manner prescribed by law." MiCh. CONST. art. X, $\S 2$. The question in both cases was what constituted a "public use" within the meaning of the constitutional provision. In both cases, the governmental 
agency justified the taking of private property and turning the property over to a private entity on the ground that this was necessary for economic development, in Hathcock for a business technology park, and in Poletown for a new automobile assembly plant. In Hathcock, the Court held that the use of the private property for economic development constituted a "public use" for constitutional purposes, overruling Poletown. The Court did not do so simply on the ground that a Court majority concluded that Poletown had been "wrongly decided." Rather the Court engaged in a careful analysis of the meaning of "public use" in the Court's decisions at the time of the ratification of the 1963 Constitution, and concluded that the transfer of private property to another private entity for economic development "implicates none of the saving elements noted by our pre1963 eminent domain jurisprudence." Hathcock, 471 Mich. at 476, 684 N.W.2d at 783. This being so, said the Court: "[w]e can only conclude, therefore, that no one sophisticated in the law at the 1963 Constitution's ratification would have understood 'public use' to permit the condemnation of defendants' properties for the construction of a business and technology park owned by private entities. Therefore, the condemnations proposed in this case are unconstitutional under art. 10 , sec. $2 . "$ Id. at 478,684 N.W.2d at 784. Thus, the Court set forth a special justification for overruling Poletown, namely that it was "inconsistent with our eminent domain jurisprudence" and was a "radical departure from fundamental constitutional principles and over a century of this Court's eminent domain jurisprudence leading up to the 1963 Constitution." Id. at 483,684 N.W. $2 \mathrm{~d}$ at 787. As the Court observed in Hathcock, in holding that the decision should have retroactive effect and be applied to all cases in which the issue was raised and preserved: "[o]ur decision today does not announce a new rule of law, but rather returns our law to that which existed before Poletown and which has been mandated by our Constitution since it took effect in 1963. Our decision simply applies fundamental constitutional principles and enforces the 'public use' requirement as that phrase was used at the time our 1963 Constitution was ratified." Id. at 484,684 N.W.2d at 788 . In the 2006 election, the Michigan voters approved a constitutional amendment incorporating the result in Hathcock into the Michigan Constitution. Mich. Const., Art. X, sec. 2, now specifically provides that: "'Public use' does not include the taking of private property for transfer to a private entity for the purpose of economic development or enhancement of tax revenues. Private property otherwise may be taken for reasons of public use as that term is understood on the effective date of the amendment to this constitution that added this paragraph." MICH. ConST., art. X, $\S 2$. Other cases involving what we have referred to as non-ideological overrulings are: People v. Starks, 473 Mich. 227, 701 N.W.2d 136 (2005), overrruling People v. Worrell, 417 Mich. 617, 340 N.W.2d 612 (1983) (holding that consent of a person under the age of 16 is not a defense to a charge of assault with intent to commit criminal sexual conduct involving penetration); People v. Williams, 475 Mich. 245, 716 N.W.2d 208 (2006) (overruling People v. Smith, 438 Mich. 715, 475 N.W.2d 333 (1991)) (holding that the 180 day rule, codified in MiCH. COMP. LAWS ANN. $\S 780.131$ (West 2010), which provides that a prison inmate who has a pending criminal charge must be tried within 180 days after the Department of Corrections delivers to the prosecutor notice of the inmate's imprisonment and requests disposition of the pending charge, applies to defendants facing mandatory consecutive sentencing upon conviction of the pending charge); Haynes v. Neshewat, 477 Mich. 29, 729 N.W.2d 488 (2007) (overruling Kassab v. Michigan Basic Property Insurance Association, 441 Mich. 433, 491 N.W.2d 545 (1992)) (holding that the public accommodation provision of the Civil Rights Act, Mich. COMP. LAWS ANN. $\S 37.2302$ (West 2010), prohibits unlawful discrimination against any individual, not just against members of the public).

144. As Justice Cavanagh stated in his dissent in Robertson: 


\section{THE Michigan SUPREME COURT AND A RETURN TO STARE DECISIS}

In the 2008 election, Chief Justice Clifford Taylor was defeated for reelection by Wayne County Circuit Judge Diane Hathaway. The ascension of Justice Hathaway to the Court in place of Chief Justice Taylor meant an end to the Court majority that had abandoned stare decisis and had engaged in an unprecedented overruling of the Court's prior decisions. As pointed out above, this unprecedented overruling of the Court's prior decisions advanced the Court majority's policy objectives of limiting tort liability and workers' compensation recovery and of making it more difficult for persons charged with a crime to avoid a conviction. Since the former Court majority completely abandoned stare decisis in order to advance its policy objectives, the legitimacy of the Court majority's abandonment of stare decisis is seriously called into question. It is respectfully submitted that a new Court majority should restore stare decisis to Michigan jurisprudence and in a principled way should confront the consequences of the former Court majority's abandonment of stare decisis.

First, the Michigan Supreme Court, with a new Court majority, should restore stare decisis to Michigan jurisprudence. The Court should refuse to overrule a prior decision simply because a majority of the Justices currently serving on the Court believe that the prior decision was wrongly decided. Instead, the Court should insist on a special justification for overruling a prior decision, as was strongly urged by Justice (now Chief Justice) Kelly and Justice Cavanagh during the period

[t]he majority's noble quest to right the alleged wrongs of the Gardner decision serves to foster an unwelcome practice of changing judicially established statutory interpretations with the makeup of the Court. Also, it fosters the undesired practice of rehashing settled debates simply because the majority concludes that someone had a better argument. This is clear because legally, nothing has changed since Gardner was decided, and no new arguments were presented to refute its analysis that were not already debated eight years ago. Strangely, the majority states that stare decisis values are furthered "by judicial decisions that are neutrally grounded in the language of the law, by a legal regime in which the public may read the plain words of its law and have confidence that such words mean what they say and are not the exclusive province of lawyers". I am puzzled by this statement because I question whether the majority can ascertain any distinction between frowning upon decisions grounded in the plain meaning of words, but are the "exclusive province of lawyers," and supporting decisions that change an already established plain meaning, and thus are the "exclusive province" of the makeup of the bench.

Robertson, at 768-69, 641 N.W.2d at 586-87 (Cavanagh, J., dissenting). 
of the unprecedented overrulings from 1999 to $2008 .{ }^{145}$ As stated earlier, guidance as to the special justification for overruling a prior decision can be found in the practice of the U.S. Supreme Court. As that Court has stated, when it considers overruling a prior decision, "its judgment is customarily informed by a series of prudential and pragmatic considerations designed to test the consistency of overruling a prior decision with the ideals of the rule of law, and to gauge the respective costs of reaffirming and overruling a prior case." 146 These considerations include: "whether the rule has proven to be intolerable simply in defying practical workability; whether the rule is subject to a kind of reliance that would lend a special hardship to the consequences of overruling and add inequity to the cost of repudiation; whether related principles of law have so far developed as to have left the old rule no more than a remnant of abandoned doctrine; or whether facts have so changed, or come to be seen so differently, as to have robbed the old rule of significant application or justification." 147 If the Michigan Supreme Court had followed these guidelines during the period of 1999-2008, it is unlikely that many of the overrulings would have taken place. ${ }^{148}$ So too, if the Michigan Supreme Court now adopts these guidelines for overruling a prior decision, we will see a considerable diminution in the number of overruling decisions by that Court.

This does not mean that we will not see some overrulings under the special justification criteria discussed above. This is particularly likely to be so in the area of statutory interpretation. As we have seen, the largest number of overruling decisions in the period from 1999 to 2008 have involved statutory interpretation, where the former Court majority insisted that the courts must follow the "plain meaning" of a statute, as the Court majority defined "plain meaning." "149 If the present Court

145. See supra notes 87,92 , and 144 . In some cases Justice Weaver has also expressed objections to the Court majority's abandonment of stare decisis. In Devillers v. Auto Club Insurance Co., Justice Weaver in her dissent stated as follows:

[i]n light of the doctrine of stare decisis and the purposes it serves, neither the defendant nor the majority have given sufficient reason to overrule Lewis. Correction for correction's sake does not make sense. The case has not been made why the Court should not adhere to the doctrine of stare decisis in this case.

Devillers at 621-22, 702 N.W.2d at 573 (Weaver, J., dissenting).

146. Casey, 505 U.S. at 854 (1992).

147. Id. at 854-55 (citations omitted).

148. The Michigan Supreme Court's decision in Hathcock, 471 Mich. 445, 684 N.W.2d 765 (2004), which overruled its prior decision in Poletown, 410 Mich. 616, 304 N.W.2d 455 (1981), would be justified under these guidelines. See discussion supra note 143.

149. See discussion supra notes 88-91, and accompanying text. 
majority were to accept the justification for overruling past decisions that had been proffered by the former Court majority, then it would be justified in overruling any statutory interpretation decision that it concluded had been "wrongly decided." It should not accept that justification. The principle of stare decisis is no less applicable when the prior decision involved statutory interpretation than when it involved constitutional or common law interpretation. There must be a special justification for overruling a statutory interpretation decision and a court is not properly performing the judicial function when it overrules a statutory interpretation decision simply because the court as currently constituted believes that the prior decision was wrongly decided.

Nonetheless, the Court's statutory interpretation decisions during the period from 1999 to 2008 , including those that did not involve the overruling of prior decisions, were based on a very narrow view of "plain meaning." Moreover, those decisions, like the overruling statutory interpretation decisions, always advanced the former Court majority's policy objectives of favoring defendants over plaintiffs in civil cases and favoring the prosecution over the defendant in criminal cases. Because of the very narrow view of "plain meaning" and the ideological basis of those decisions, there may be a special justification for overruling some of them.

The most likely justification for overruling a statutory interpretation decision is that the decision defies practical workability. This justification is clearly present with respect to the decision in Kreiner $v$. Fischer. ${ }^{150}$ There, the Court held in a 4-3 decision, with the former Court majority on one side, and Justices Cavanagh, Weaver and Kelly of the current Court in dissent, that the "serious impairment of body function" threshold set by the no-fault act ${ }^{151}$ in order for an automobile accident victim to be able to maintain a tort action meant "an objectively manifested impairment of an important body function that affects the person's general ability to lead his or her normal life." 152 The Court further held that whether the threshold was met in a particular case was a question for the court rather than for the jury. ${ }^{153}$ The dissenting Justices contended that it was a question of fact for the jury to decide whether the plaintiff satisfied the "serious impairment of body function" standard and that the role of the reviewing court was to "compare the plaintiff's pre and post-accident life and determine whether the impairment has an

150. Kreiner v. Fischer, 471 Mich. 109, 683 N.W.2d 611 (2004).

151. Мich. Comp. LaWS ANN. § 500.3135(1) (West 2010).

152. Kreiner, 471 Mich. at 129,683 N.W.2d at 628.

153. Id. at 121,683 N.W.2d at $619-20$. 
influence on most, but not all, of the plaintiff's capacities to lead his preaccident lifestyle." 154

It is clear that application of the Kreiner test would impose a major hurdle for a person injured in an automobile accident to satisfy the "serious impairment of body function" standard and so be able to maintain a tort action to recover for the injuries. This is what has happened in practice, with the result that many seriously-injured automobile accident victims are unable to maintain a tort action. ${ }^{155}$ It can be contended that the result that many seriously-injured automobile accident victims are unable to maintain a tort action was not what was intended by the Michigan Legislature when it adopted the no-fault law, and that where the accident impacted the victim's ability to lead his or her pre-accident lifestyle, the legislature intended that a tort action should be permitted. Similarly, it can be contended that, by the use of this standard the legislature intended to reduce somewhat the number of tort actions arising out of automobile accidents, but did not intend to preclude seriously-injured automobile accident victims from obtaining tort recovery and to a large extent bar such actions. If the Michigan Supreme Court concludes that the result of the application of the Kreiner test defeats the legislative purpose in the enactment of the no-fault act, then the decision in Kreiner "defies practical workability," and there is a special justification for overruling it. ${ }^{156}$

The matter of the Court's following stare decisis and adhering to prior decisions has produced an interesting turnaround on the Court. The former Court majority, which had completely abandoned stare decisis in the period from 1999-2008 by overruling an unprecedented number of

154. Id. at 140-44, 683 N.W.2d at 629-31 (Cavanagh, J., dissenting).

155. See, e.g., Berishaj v. Shkreli and Auto Club Group Ins. Co., No. 28709, 2009 Mich. Ct. App. LEXIS 2094 (Oct. 6, 2009) (holding that although evidence established objective manifestation of neck, shoulder, back and leg injuries, and her ability to work and to walk were impaired, since the plaintiff was able to return to work fifteen months after he accident, and despite some pain and concentration problems, was able to perform her job, the Court of Appeals, under Kreiner, is "legally compelled to conclude that the trial court did not err in holding that plaintiff failed to establish that her impairments 'affected [her] general ability to conduct the course of ... her normal life."' Id. at*8).

156. The Court has recently granted leave to appeal in a case in which the Court is asked to reconsider and overrule Kreiner. McCormick v. Gen. Motors Corp. and Carrier, Sup. Ct. Case No. 136738, leave to appeal granted, 485 Mich. 851,770 N.W.2d 357 (2009). In a 4-3 holding, the Court overruled Kreiner on the ground that the decision was a "departure from the plain language of MCL 500.3135(7) [and] defies practical workability." McCormick v. Carrier, No. 136738, 2010 WL 3063150, at *1, *13 (Mich. July 31, 2010). Justice Cavanagh wrote the Opinion of the Court and was joined by Chief Justice Kelly and Justices Weaver and Hathaway. Id. at *17. Justices Corrigan, Markman and Young dissented. Id. at * 45 . 
prior decisions, is now accusing the new Court majority of being inconsistent by disregarding prior decisions, ${ }^{157}$ and by granting leave in some cases, with directions to the parties to brief the questions of whether some prior decisions should be overruled.

In addition to the possible overruling of Kreiner, my research has disclosed six other cases where the order granting the application for leave to appeal directed the parties to brief the question of whether a prior decision should be overruled. Two of these cases involve a reconsideration of overruling decisions, one directly and one indirectly, which, as I will discuss shortly, should indeed be reconsidered by the Court. ${ }^{158}$ Of the remaining four, two involved standing to seek judicial

157. According to Justice Markman, concurring in part and dissenting in part in Potter v. McCleary, 774 N.W.2d 1 (Mich. 2009), the new Court majority implicitly overruled a precedent by refusing to follow its holdings, and prior statements by Chief Justice Kelly and Justice Cavanagh, emphasizing the importance of precedents, "are only pertinent where precedents with which the majority agrees are at stake." Potter, 774 N.W.2d at 44 (Markman, J., concurring in part and dissenting in part). The issue in that case was whether in a malpractice action against a professional corporation predicated on its vicarious liability for a licensed health care provider rendering professional service, a notice of intent to sue (NOI) had to be provided to the professional corporation, pursuant to MCLA $\S 691.2912 b(4)$ (West 2010). The four justices comprising the new majority, in an opinion by Justice Hathaway, held that the statute required that an NOI be provided to the professional corporation, and that the notice provided in that case was sufficient to satisfy the statutory requirements. Potter, 774 N.W.2d at 16. Justices Corrigan, Young, and Markman, disagreed with the majority on some issues in the case and among themselves on other issues in the case. Chief Justice Kelly concurred "for the sole purpose of responding to Justice Markman's comments attacking the majority's respect for the doctrine of stare decisis." Potter, 774 N.W.2d at 17. She contended that he was repeating a claim that he and Justices Corrigan and Young have published numerous times in the current term, as they dissented from the new majority's decisions in particular cases. She then attempted to demonstrate that in these cases the new majority was not ignoring precedents, but rather that these cases were distinguishable from the precedents on which the majority relied. She concluded as follows: "[i]n summary, the accusation that the Court has been ignoring precedent is incorrect. Had other Justices been in the majority in some of the decisions complained about, they might well have extended existing precedent to a new area of the law. But the refusal of those in the majority in this case to so extend precedent is quite different from a refusal on their part to apply it. This is a distinction that Justices Markman, Corrigan, and Young would do well to concede." Potter, 774 N.W.2d at 18 (Kelly, C.J., concurring). It is somewhat ironic that the three members of the former majority who were responsible during a tenyear period for overruling by my count some thirty-eight prior decisions, thirty-four of them on purely ideological grounds, would become advocates for following precedent now that they are in the minority. Thus far, the new majority has not overruled any of the overruling decisions of the former majority. But it should not be surprising, as Chief Justice Kelly says, that the new majority is not willing to extend those decisions.

158. Colaianni v. Stuart Frankel Dev. Corp., 77 N.W.2d 410 (Mich. 2010) (directing a reconsideration of Trenatdue v. Buckler Automatic Lawn Sprinkler Co., 479 Mich. 378, 738 N.W.2d 664 (2007), which overruled Chase v. Sabin, 445 Mich. 190, 516 N.W.2d 60 
review for alleged statutory violations, ${ }^{159}$ one involved recovery of living expenses as a part of personal protection insurance benefits, ${ }^{160}$ and one involved recovery for "loss of opportunity to survive" in medical malpractice cases. ${ }^{161}$

The fact that the Court has directed reconsideration of the prior decisions does not mean, of course, that the Court will necessarily overrule them. It may decide, after briefing and oral argument, that there is not a special justification for doing so. The point to be emphasized is

(1994)). See supra note 111 and accompanying text. Univ. of Michigan Regents v. Titan Ins. Co., 769 N.W.2d 646 (Mich. 2009) (directing a consideration of two cases involving tolling of the "one year back" limitation of MCLA $\S 500.3145(1)$ for recovering no fault personal protection insurance benefits that were based on the decision in Devillers, 473 Mich. 562, 702 N.W.2d 539 (2005), which overruled Lewis v. Detroit Auto. Inter-Ins. Exch., 426 Mich. 93, 393 N.W.2d 167 (1986)). See supra note 103 and accompanying text. In the Titan case, the Court overruled Cameron v. Auto Club Ins. Ass'n., 476 Mich. 55, 718 N.W.2d 784 (2006), and held that MCL 500.3145(1) exempted the state entities listed in MCL 600.5821(4) from the one-year back rule. Regents of the Univ. of Michigan v. Titan Ins. Co., Mich., No. 136905, 2010 WL 3037798, at * (Mich. July 31, 2010). Chief Justice Kelly wrote the opinion of the Court and was joined by Justices Cavanagh, Weaver, and Hathaway. $I d$. at $* 8$. Justices Corrigan, Markman and Young dissented. Id. at * $1,{ }^{*} 13,{ }^{*} 16$.

159. Anglers of the AuSable, Inc. v. Dep't of Envtl. Quality, LLC., 485 Mich. 1067, 777 N.W.2d 407 (Mich. 2010) (directing a reconsideration of Michigan Citizens v. Nestle Waters, 479 Mich. 280, 737 N.W.2d 447 (2007), and Preserve the Dunes v. Department of Environmental Quality, 471 Mich. 508, 684 N.W.2d 847 (2004)); Lansing Sch. Ass'n v. Lansing Bd. of Educ., 485 Mich. 966, 774 N.W.2d 689 (Mich. 2009) (directing a reconsideration of Lee v. Macomb County Bd. of Comm'ns, 464 Mich. 726, 629 N.W.2d 900 (2001)). In the Lansing case, the Court overruled Lee v. Macomb County. Bd. of Comm'rs, 464 Mich. 726, 629 N.W.2d 900 (2001) and its extension in later cases on the ground that the standing doctrine adopted in that case "lack[ed] a basis in the Michigan Constitution and [was] inconsistent with Michigan's historical approach to standing." Lansing Sch. Educ. Assoc. v. Lansing Bd. of Educ., No. 138401, 2010 WL 3037733, at *1 (July 31, 2010). Under the restored standing doctrine, "where a cause of action is not provided at law, then a court should, in its discretion, determine whether a litigant has standing ... [based on] a special injury or right or substantial interest, that [would] be detrimentally affected in a manner different from the citizenry at large," or because, in the context of a statutory scheme, "the Legislature had intended to confer standing on the litigant." Id. at *8. The Court also held in that case that teachers had "standing to sue the school board for failing to comply with its statutory duty to expel students that have allegedly physically assaulted those teachers." $I d$. at * 1 . Justice Cavanagh wrote the opinion of the Court and was joined by Chief Justice Kelly and Justices Weaver and Hathaway. Id. at ${ }^{*} 1,10$. Justices Corrigan, Markman and Young dissented. Id. at *15.

160. Hoover v. Michigan Mut. Ins. Co., 485 Mihc. 881, 772 N.W.2d 338 (Mich. 2009) (directing a reconsideration of State Farm Mut. Auto. Ins. Co., 472 Mich. 521, 697 N.W.2d 895 (2005)).

161. Edry v. Adelman, 485 Mich. 901, 772 N.W.2d 427 (Mich. 2009) (directing a reconsideration of Wickens v. Oakwood Healthcare System, 465 Mich. 53, 631 N.W.2d $686(2001))$. 
that if the Court as reconstituted is committed to restoring stare decisis to Michigan jurisprudence, it must find a special justification for overruling any prior decision and cannot take a "turnabout is fair play" approach to overruling the prior decisions of the former Court majority with which it may disagree. ${ }^{162}$

Chief Justice Kelly has recently reaffirmed the commitment to stare decisis and the need for a special justification for overrulings that were the basis for her objections and those of Justice Cavanagh and more recently of Justice Weaver to the unprecedented number of overrulings by the former Court majority. She stated as follows:

A stare decisis analysis should always begin with a presumption that upholding precedent is the preferred course of action. Next, the court should determine whether a compelling justification exists to overturn the precedent. A compelling justification is not a mere belief that the precedential case was wrongly decided or that the Court as currently composed would have decided the case differently. The factors listed in this opinion should be used on a case-by-case basis to determine whether a compelling justification exists to overrule an existing precedent. ${ }^{163}$

Chief Justice Kelly went on to say that "[a] compelling justification is not a mere belief that a precedential case was wrongly decided or that the Court, as currently composed, would have decided the case differently. Rather, in determining whether a compelling justification

162. A discussion of whether there is a special justification for overruling any or all of these decisions is beyond the scope of the present article.

163. Petersen v. Magna Corp., 484 Mich. 300, 338, 773 N.W.2d 564, 584-85 (2009) (Opinion of Kelly, J.). In her opinion in Petersen, Chief Justice Kelly noted that in Robinson, the Court had established a test to determine when it should depart from stare decisis. Under that test, the first question to consider in deciding to overrule precedent was whether the earlier decision was wrongly decided. Next, the court should consider (1) whether the decision defies practical workability, (2) whether reliance interests would work an undue hardship if the decision were overturned, and (3) whether changes in the law or facts no longer justify the decision. However, she concluded that as applied by the former Court majority, the application of the test had proven "superficial and cursory," that "not once" has the Court cited it as a basis for upholding a prior decision and that "Robinson's statement that a wrongly decided case should 'invariably' be overruled was a chilling signal that a conclusion that precedent has been wrongly decided is sufficient justification for overruling it." Petersen, 484 Mich. at 316, 773 N.W.2d at 571-72. She concluded that the large number of overrulings by the former Court majority "alone suffice to show that Robinson is insufficiently respectful of precedent," and so she would "modify it by shifting the balance back in favor of precedent and expanding on Robinson's list of factors to consider in applying stare decisis." Petersen, 484 Mich. at 317,773 N.W.2d at 572. 
exists, the Court should consider several criteria, none of which standing alone, is dispositive." ${ }^{164}$ These criteria include (1) whether the rule has proven to be intolerable because it defies practical workability; (2) whether reliance on the rule is such that overruling it would cause a special hardship and inequity; (3) whether related principles of law have so far developed since the rule was pronounced that no more than a remnant of the rule has survived; (4) whether facts and circumstances have so changed, or come to be seen so differently, as to have robbed the old rule of significant application or justification; (5) whether other jurisdictions have decided similar issues in a different manner; (6) whether upholding the rule is likely to result in serious detriment prejudicial to public interests; and (7) whether the prior decision was an abrupt and largely unexplained departure from precedent. ${ }^{165}$ She concluded as follows: "Not all of these factors will be applicable in every case. Nor is there a magic number of factors that must favor overruling a case in order to establish the requisite compelling justification. Rather I believe that the conclusion about whether these factors support finding a compelling justification should be reached on a case-by-case basis."

The criteria outlined by Chief Justice Kelly essentially embody the criteria employed by the U.S. Supreme Court in deciding whether there is special justification for overruling a prior decision. ${ }^{167}$ It may be assumed that this criteria will be followed by the other members of the new Court majority, and that the Court as now constituted will only overrule a prior decision when the overruling can be justified by the application of these criteria in the particular case. ${ }^{168}$

The question remains as to what the Michigan Supreme Court as reconstituted with a new Court majority should do about the unprecedented number of overrulings during the 1999-2008 period. These decisions, of course, remain in effect, and must be followed by the lower courts in Michigan unless and until the Michigan Supreme Court specifically overrules them. At the same time, these overruling decisions lack the legitimacy of other decisions of the Michigan Supreme Court, because they were decisions by a Court majority that had abandoned the principle of stare decisis in order to advance the Court majority's policy

164. Petersen, 484 Mich. at 320, 773 N.W.2d at 574.

165. Id.

166. $I d$.

167. See discussion supra notes $138-39$, and accompanying text. In this regard, there is no difference between "substantial" and "compelling" with respect to the justification for overruling a prior decision.

168. The Court's treatment of the cases in which it has specifically directed a reconsideration of prior decisions, see supra notes 158-61, will demonstrate the Court's application of the criteria set forth by Chief Justice Kelly in her opinion in Petersen. 
objectives. ${ }^{169}$ It is my submission that these overruling decisions should not be given stare decisis effect by the Michigan Supreme Court, and that as far as the Court itself is concerned, these decisions should stand on no stronger footing than the decisions that they overruled. ${ }^{170}$

\section{CONCLUSION}

The Michigan Supreme Court does not have any power under the Michigan Constitution or the Michigan Court Rules to overrule prior decisions except in the context of rendering a decision in a particular case. This being so, we must look to the structural ways in which those decisions could be called into question and possibly overruled by the newly constituted Court. Michigan Court Rule 7.302 governs applications for leave to appeal to the Michigan Supreme Court, and a ground for leave to appeal under Rule 7.302(B)(3) is that "the issue involves legal principles of major significance to the state's jurisprudence." Where a decision of the Michigan Court of Appeals has applied as controlling precedent a decision of the Michigan Supreme Court that overruled a prior decision of that Court, the applicant for leave to appeal may properly argue that leave should be granted so that the Court may reconsider the overruling decision and decide whether the overruling decision or the overruled decision should be followed. ${ }^{171}$

169. I exclude the four non-ideological overrulings from this observation. See supra note 143 .

170. As the conclusion of her discussion of stare decisis and the criteria for overruling prior decisions in Petersen, Chief Justice Kelly stated, "However, consistent with United States Supreme Court precedent, I would accord a lower level of deference to cases that represent a recent departure from the traditional notions of stare decisis." Petersen, 484 Mich. at 338, 773 N.W.2d at 585.

171. Two of the cases this term where the Order granting the application for leave to appeal directs the reconsideration of prior cases involve this situation. See supra note 158 and accompanying text. The argument that the Court should grant leave to appeal on this basis would not be limited to reconsidering the overruling decisions in the 1999 to 2008 period. It is interesting to note that in 1998, when only Justice Taylor of the later Court majority was on the Court, he authored an opinion, joined in by Justices Brickley, Boyle and Weaver, in Graves, 458 Mich. 476, 581 N.W.2d 229, where the Court held that the erroneous submission of a first degree murder charge to the jury was harmless error, since the jury returned a verdict of guilty of voluntary manslaughter. The Court overruled the earlier decision of Vail, 393 Mich. 460, 227 N.W.2d 535, which held that the submission to the jury of an offense that was not supported by the evidenced required automatic reversal, even though the jury found the defendant guilty of a lesser offense that was supported by the evidence. Justice Cavanagh, joined by Justice Kelly and then Chief Justice Mallett, dissented. Justice Taylor contended that the decision to overrule Vail was based on prudential and pragmatic considerations, principally that the Vail rule of automatic reversal was inconsistent with the Court's subsequent harmless error jurisprudence. Graves, 458 Mich. at 480-88, 581 N.W.2d at 231-35. This reason would 
When the Court grants leave to appeal on this basis, the Court could proceed in one of two ways. The Court could decide whether there was a "special justification" for the overruling decision, and if it concludes that there was not, it could overrule the overruling decision and reinstate the overruled decision for this reason. Or, the Court could take the position that since the overruling decision lacks legitimacy, the Court will now revisit the substantive issue and decide it anew without regard to either the overruling or the overruled decision. If the Court proceeds in this manner and reaches the same result as was reached by the former Court majority in the overruling decision, then that decision will now have a legitimacy that it lacked before. Whether the Court now overrules the overruling decision or reaches the same result that was reached in the overruling decision and so in effect affirms it, the Court to some degree will have restored the principle of stare decisis to Michigan jurisprudence.

The Court could also make the policy determination to provide expressly for the reconsideration of overruled decisions. In accordance with the amendment procedure set forth in Michigan Court Rule 1.201, the Court could amend Court Rule 7.302(B) to add a new ground for leave to appeal. The new ground for appeal could read as follows: "The decision of the Michigan Court of Appeals has applied as controlling precedent a decision of the Michigan Supreme Court that overruled a prior decision of that Court, and there are good reasons for the Court to reconsider the overruling decision and to decide whether or not to reinstate the overruled decision." This policy determination for a proposed amendment to Court Rule 7.302(B) would be highly controversial and would generate an extensive amount of conflicting commentary under the notice requirements of Michigan Court Rule 1.201. This being so, the Court may not wish to go this route. Additionally, it may not be necessary for the Court to do so if the Court signifies its willingness to grant leave to appeal to reconsider its overruling decisions when an application for leave to appeal on this basis is made under existing Court Rule 7.302(B)(3).

It is unfortunate that a majority of the Michigan Supreme Court in the period from 1999 to 2008 made the choice to disregard the principle of stare decisis and to overrule a large number of prior decisions in order to advance the Court majority's policy objectives. It is hoped that the Michigan Supreme Court as reconstituted with a new Court majority will

furnish a special justification for the overruling in this case, and Graves would have a stronger claim to be given stare decisis effect. 
return to the principle of state decisis and, in so doing, will reconsider at least some of the large number of overruling decisions of the former Court majority. It is time to return to stare decisis in Michigan. 